\title{
Metallogenic epoch of the Jiapigou gold belt, Jilin Province, China: Constrains from rare earth element, fluid inclusion geochemistry and geochronology
}

\author{
Zhixin Huang ${ }^{1,2}$, Wanming Yuan ${ }^{1, *}$, Changming WAnG $^{2}$, \\ Xiangwei LiU ${ }^{3}$, XiaOtong Xu ${ }^{4}$ and Liya YAnG ${ }^{2}$ \\ ${ }^{1}$ State Key Laboratory of Geological Processes and Mineral Resources, China University of Geosciences, \\ No. 29, Xueyuan Road, Beijing 100083, People's Republic of China. \\ ${ }^{2}$ Beijing Research Institute of Uranium Geology, P. O. Box 9818, Beijing 100029, People's Republic of China. \\ ${ }^{3}$ Shaanxi Province Institute of Geological Survey, No. 66, Jixiang Road, Xi'an 710065, \\ People's Republic of China. \\ ${ }^{4}$ Development Research Centre, China Geologic Survey, No. 45, Fuwai Street, Beijing 100037, \\ People's Republic of China. \\ *Corresponding author.e-mail: ywm010@yahoo.com
}

The Jiapigou gold belt is located on the northern margin of the North China Craton, and is one of the most important gold-mining and production regions in the circum-Pacific metallogenic zone. Research has been conducted in this area since the 1960s, however, the timing of the gold mineralisation is still unresolved, and an ideal metallogenic model has not been well established. To address these questions, a systematic geological, geochemical and geochronological investigation was conducted. The study revealed that (i) the gold-bearing quartz veins can be divided into two groups, earlier and later gold-bearing quartz veins according to their occurrence and the geochemical characteristics, (ii) the geochemical characteristics of the ore bodies, while similar to granite, are clearly different from the altered rock, and (iii) the geochemical characteristics of the later gold-bearing quartz veins have more similarity to the altered rock than the earlier gold-bearing quartz veins do. Therefore, we conclude that two independent stages of metallogenesis within the Jiapigou gold deposit area are related to magmatic activity in the Palaeoproterozoic and the Yanshanian stage of the Mesozoic, that the ore-forming fluids are mainly of magmatic origin, and that magma contamination by the altered rock was stronger in the Mesozoic. Zircon LA-ICP-MS U-Pb data show that the age of the Palaeoproterozoic granite is $\sim 2426.0 \mathrm{Ma}$ and that of the Mesozoic granite is $\sim 166.2 \mathrm{Ma}$; these ages can be interpreted as the maximum ages of the two periods of gold mineralisation. In addition to investigating the geotectonic and regional structure of the Jiapigou gold belt, this study also proposes that the WNW-trending zone of gold mineralisation is a result of a magmatic event within the basement in the early Palaeoproterozoic, and that largescale sinistral strike-slip displacements of the Huifahe and Liangjiang Faults in the late Middle Triassic (Yanshanian epoch) controlled the later tectono-magmatic event and the NNE-ENE-trending zone of gold mineralisation.

Keywords. Metallogenic epoch; rare earth elements; fluid inclusion; zircon U-Pb dating; Jiapigou gold belt; northeast China. 


\section{Introduction}

Rare earth elements (REE) are important geochemical indicators that can be used to reveal the origin of ore-forming materials and fluids, determine the age of rocks and ores (Schwinn and Markl 2005; Jackson et al. 2007), trace the evolution of hydrothermal systems, constrain the conditions of wall-rock alteration and ore formation, and evaluate the genesis of ore deposits (Henderson 1984; Kessel et al. 2005; Suayip 2010). Because REE concentrations and patterns are directly linked to the source of the metal, the physico-chemical character of the hydrothermal fluid that carries the REE and the geochemical ambience of metal traps, also might indirectly indicate different epochs of the mineralisation (Deng et al. 2008; Reezaee et al. 2009; Ma et al. 2010; Anand and Balakrishnan 2011).

The Jiapigou gold belt in Jilin Province, northeast China, has been an important area of gold mining and production for more than 190 years. The region produces about $1500 \mathrm{~kg}$ of gold per year and currently has more than 100 ton of gold reserves. A large volume of geological research has been conducted in this area since the 1960s, but little has been published in the international literature, and most of the studies have focused on the mineralogy, petrology, geochemistry, orecontrolling structures, and geochronology of gold mineralisation and fluid evolution (Sun et al. 1996; Shen et al. 1999; Miao et al. 2005; Deng et al. 2009). However, the timing and genetic model of the gold mineralisation are still controversial, due to disputes about the origin and age of the ore-forming fluids. The proposed timing of the gold mineralisation ranges from late Archaean to Jurassic depending upon different rock types and radiogenic isotopic dating methods used (Wang 1994; Sun 1995; Cheng et al. 1996; Sun and Feng 1997; Dong et al. 1999; Shen et al. 1999; Luo et al. 2002). Several geochronological methods have been adopted and several rock types have been analyzed including: $\mathrm{Rb}-\mathrm{Sr}$ dating of igneous rocks (granite, granodiorite, and granite porphyry), $\mathrm{K}-\mathrm{Ar}$ dating and SHRIMP U-Pb dating of metamorphic rocks (amphibolites and gneiss), and Ar-Ar dating of early and late phase quartz veins. Regarding the genetic model for the gold deposits, Shen et al. (1999) and Cheng et al. (1996) considered the gold deposits to be a typical late-Archaean greenstone lode-gold type deposit, while Sun and Feng (1997) considered the deposits to be related to Yanshannian magmatism. Sun (2003), Zhao et al. (2006) and Xie et al. (2008) proposed a multistage evolutionary model based on geochronological data, and Goldfarb et al. (1998) interpreted the Jiapigou gold deposits as orogenic gold deposits related to
North China craton-marginal Phanerozoic orogenic events.

To confirm the metallogenic epoch of the Jiapigou gold deposits, we attempt to reveal the origin of the ore-forming materials and fluids by analysing the characteristics of the REE of the ore body, granite and amphibolite that are most relevant to the mineralisation and by investigating the characteristics of fluid inclusions. We then attempt to determine the stage and epoch of mineralisation using $\mathrm{LA}-\mathrm{ICP}-\mathrm{MS} \mathrm{U}-\mathrm{Pb}$ dating of zircons in the granite, to develop a genetic model of the Jiapigou gold belt.

\section{Geological setting}

\subsection{Regional geology}

The Jiapigou gold belt is situated in the Jiapigou shear zone (fault) in the northeastern wedge of the North China Craton (NCC). The tectonic evolution of the region is closely related to the Siberian Plate to the north, the Yangtze Craton to the south and the Pacific Plate to the east. In this region, the NCC is also known as the Longgang high-grade terrane, which is separated from the central Asian orogenic belt (CAOB) by the Huifahe and Jiapigou Faults to the north and the east, respectively (figure 1a, b). The Huifahe fault represents a branch of the deep-seated Tan-Lu Fault, which is mostly covered by Cenozoic sediments and basalts and is locally intruded by Mesozoic granites. The WNW-trending Jiapigou Fault is intruded by Phanaerozoic and Mesozoic granites and is truncated by the Huifahe Fault to the northwest and the Liangjiang Fault to the southeast. This fault has experienced at least two stages of deformation, including early ductile shearing and late brittle deformation (Sun 1995). Rocks in the Longgang high-grade terrane comprise grey gneisses that are mainly composed of NeoArchaean-Palaeoproterozoic trondhjemitetonalite-granodiorite (TTG) rocks that have been subjected to granulite-facies and amphibolitefacies metamorphism. These gneisses have a wholerock $\mathrm{Rb}-\mathrm{Sr}$ isochron age of $2971 \mathrm{Ma}$ (Cheng et al. 1996) and zircon U-Pb ages of $2491 \mathrm{Ma}$ (Shen et al. 1999). The eastern part of the Jiapigou gold belt is the Jiapigou granite-greenstone belt. After cratonisation of the Archaean terrain, these rocks have been subjected to multiple periods of tectonomagmatism, including the Variscan, Indo-Chinese and Yanshan epochs. These events strongly influenced the greenstone belt and formed a large amount of crust-derived anatectic granites and intermediate to acidic dikes in the study areas. The granitoids cover more than $65 \%$ of the entire gold 


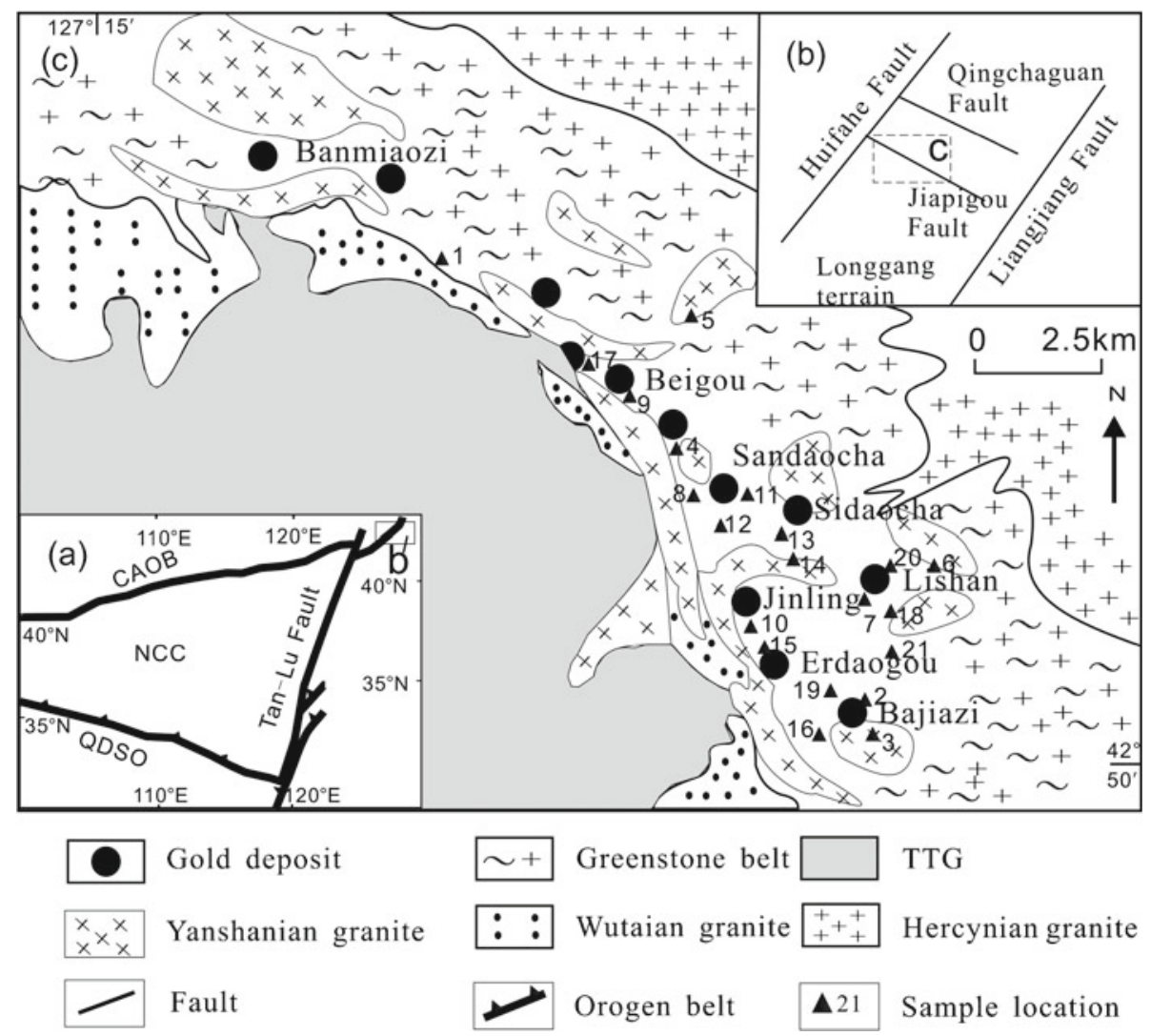

Figure 1. Geologic map of the Jiapigou gold ore belt, northeastern China. (a) Simplified map showing the location of the Jiapigou gold belt within the regional tectonic framework of northeast China. (b) Simplified map showing the major regional faults and location of the Jiapigou gold belt. (c) General geologic map of the Jiapigou gold belt, showing the distribution of the stratigraphic units and the major gold deposits (IMOB, NCC and QDSO represent the Inner Mongolian-Daxinganling orogenic belt, North China Craton and Qinling-Dabie-Sulu orogen respectively. The numbers represent samples 1: JP18, 2: JP46, 3: JP68-1, 4: JP87, 5: JP16, 6: JP20, 7: JP4-1, 8: 3DC03, 9: BG21, 10: JL6D, 11: JP42, 12: JP85-1, 13: SDC5D, 14: 4DC11D, 15: EDG01, 16: JP44-1, 17: HG01, 18: XXT01, 19: BJZ06, 20: XXT05, 21: JP71).

belt, while the greenstone cover less than $35 \%$ of the region.

\subsection{Deposit geology}

More than 20 gold deposits and 100 occurrences have been delineated in the Jiapigou area (figure 1c). Of these, the Lishan, Erdaogou (figure 2), Bajiazi, Sidaocha, Sandaocha, Beigou and Banmiaozi ore deposits are the largest. The ore deposits can be divided into gold-bearing quartz vein types (figure 3a) and disseminated ore types (ores with gold-bearing disseminated quartz) (figure 3b) (Liu et al. 2003), as well as altered rock types (figure 3c) that were recently discovered during our field work. Quartz veins are the dominant ore type, accounting more than $85 \%$ of the total gold reserve and production of the region. Nearly all the gold deposits and prospects are confined to a $40 \mathrm{~km}$ long, 4-10 km wide, WNW-trending belt called the Jiapigou ductile shear zone, which is located between the TTG terrane and the granitic province. These deposits are controlled by the shear zone and its related structural features. Additional gold mineralisation has also been detected in intensely foliated rocks. Ore deposits near the WNW-trending main Jiapigou shear zone, such as the Banmiaozi, Laoniugou, Xiaobeigou, Miaoling and Erdaogou deposits, are WNW-trending, while the ore deposits far from the main shear zone, such as the Sandaocha, Sidaocha, Lishan and Bajiazi deposits, trend NNE or NE-ENE.

Most of the quartz veins in all the deposits dip from $40^{\circ}$ to $80^{\circ} \mathrm{WNW}$ or NNE-ENE, and individual veins are generally $100-300 \mathrm{~m}$ (max. $730 \mathrm{~m})$ long, 0.5-1.5 m (max. $17 \mathrm{~m})$ wide (figure 2a) and 500-1200 m deep (figure 2b). Most of them are not exposed at the surface but are extensive underground. The gold belt is characterised by a large variety and complex distribution of magmatic dikes and rock types, such as quartz diorite, granodiorite, granite, granodioriteporphyry, granite-aplite, granite porphyry, felsite, 
diabase, and lamprophyre, in addition to a large occurrence of gold bearing and barren quartz veins. Most of the dikes have similar attitudes and are associated with, or have a symbiotic relationship with the quartz veins (figure 4). Field observations confirm that the quartz veins are cut by the granodiorite dikes (figures $2 \mathrm{~b}, 4$ ), and these dikes formed later than or coeval with the gold mineralisation. The wall rock is dominated by the regional metamorphic rocks that are mainly composed of amphibolite and hornblende gneiss, which are the result of Archaean granulite to amphibolitesfacies metamorphism of the trondhjemite-tonalitegranodiorite (TTG) rocks.

Alteration in the Jiapigou gold deposits is generally restricted to the mylonitised zones and mainly includes K-feldspathisation, silicification, phyllic alteration, pyritisation, chloritisation, epidotisation, carbonisation and tourmalinisation. Both horizontal and vertical alteration zonations can clearly be observed (figure $3 \mathrm{~d}$ ). The mineralisation type and intensity, however, may vary based on the location and lithology of the host rocks.

According to the paragenetic sequences and the crosscutting relationships of the lodes, four stages of gold mineralisation occurred in this area, including stage I (pyrite-quartz veins), stage II (quartz-pyrite), stage III (polymetallic), and stage IV (quartz-calcite). Stage I formed the main body of quartz veins, while stages II and III were the main stages of gold enrichment.

\subsection{Petrology and mineralogy}

\subsubsection{Gold-bearing quartz veins}

The gold-bearing quartz veins in the mineralised areas are white to greyish-white and have similar metallic and gangue mineral compositions as the disseminated ores. Metallic minerals, accounting for $<10$ vol. $\%$ of the ores, include pyrite, chalcopyrite, galena, sphalerite (figure 3e), pyrrhotite magnetite, haematite, native gold, electrum and calaverite. The gangue minerals are dominated by quartz and feldspar, with minor sericite, chlorite, calcite, epidote (figure $3 \mathrm{f}$ ), apatite, ankerite, and barite. Pyrite is the major carrier of gold minerals and occurs as automorphic-hypautomorphic granular textures (figure $3 \mathrm{~g}$ ) in the deposits near the Jiapigou shear zone; occurrences in the deposits away from the shear zone are mainly hypautomorphic-xenomorphic (figure $3 \mathrm{~h}$ ) with few automorphic granular textures.
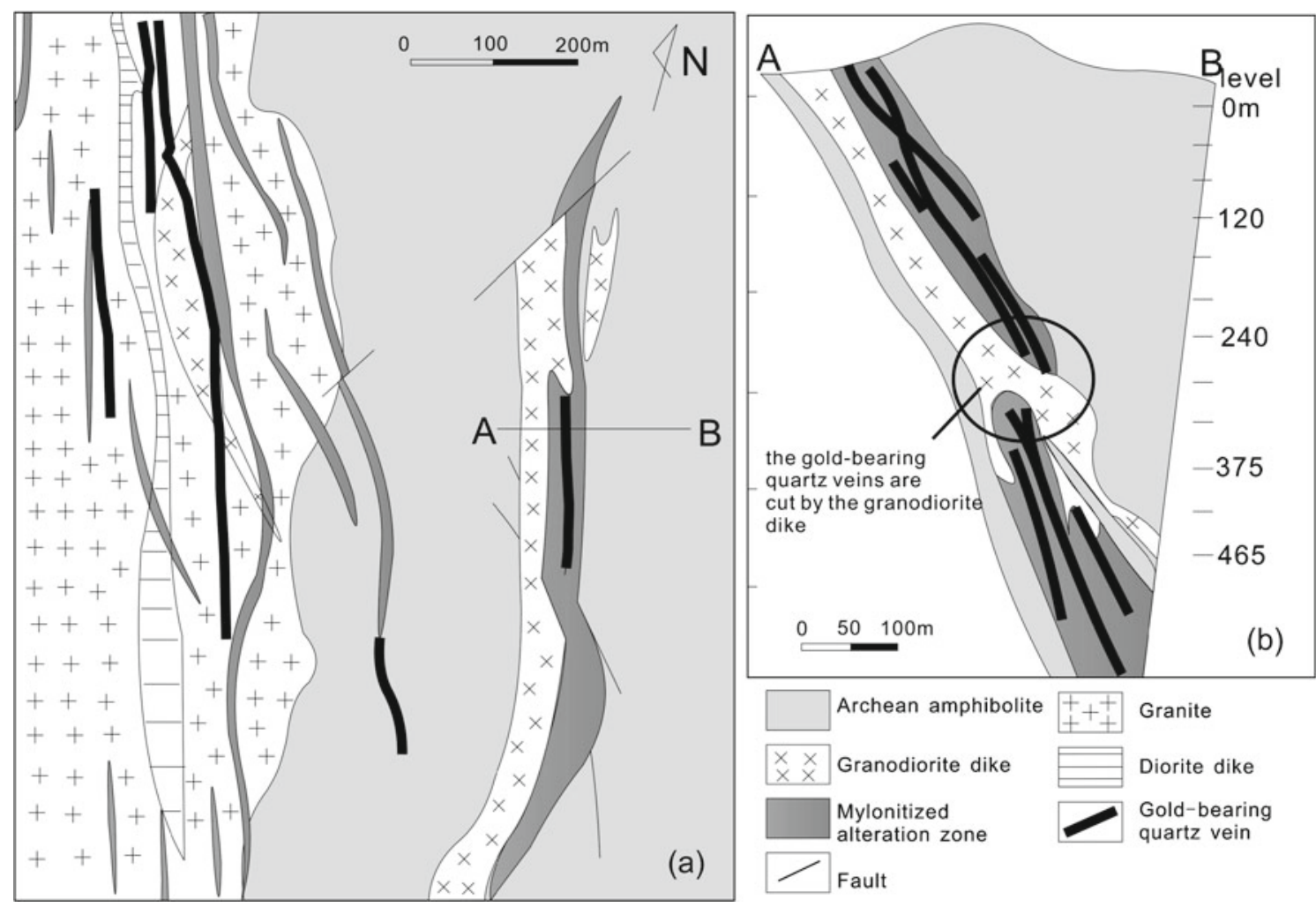

Figure 2. (a) Geologic map of a representative gold deposit (Erdaogou deposit) and (b) cross section along line A-B in (a) (after Miao et al. 2005). 

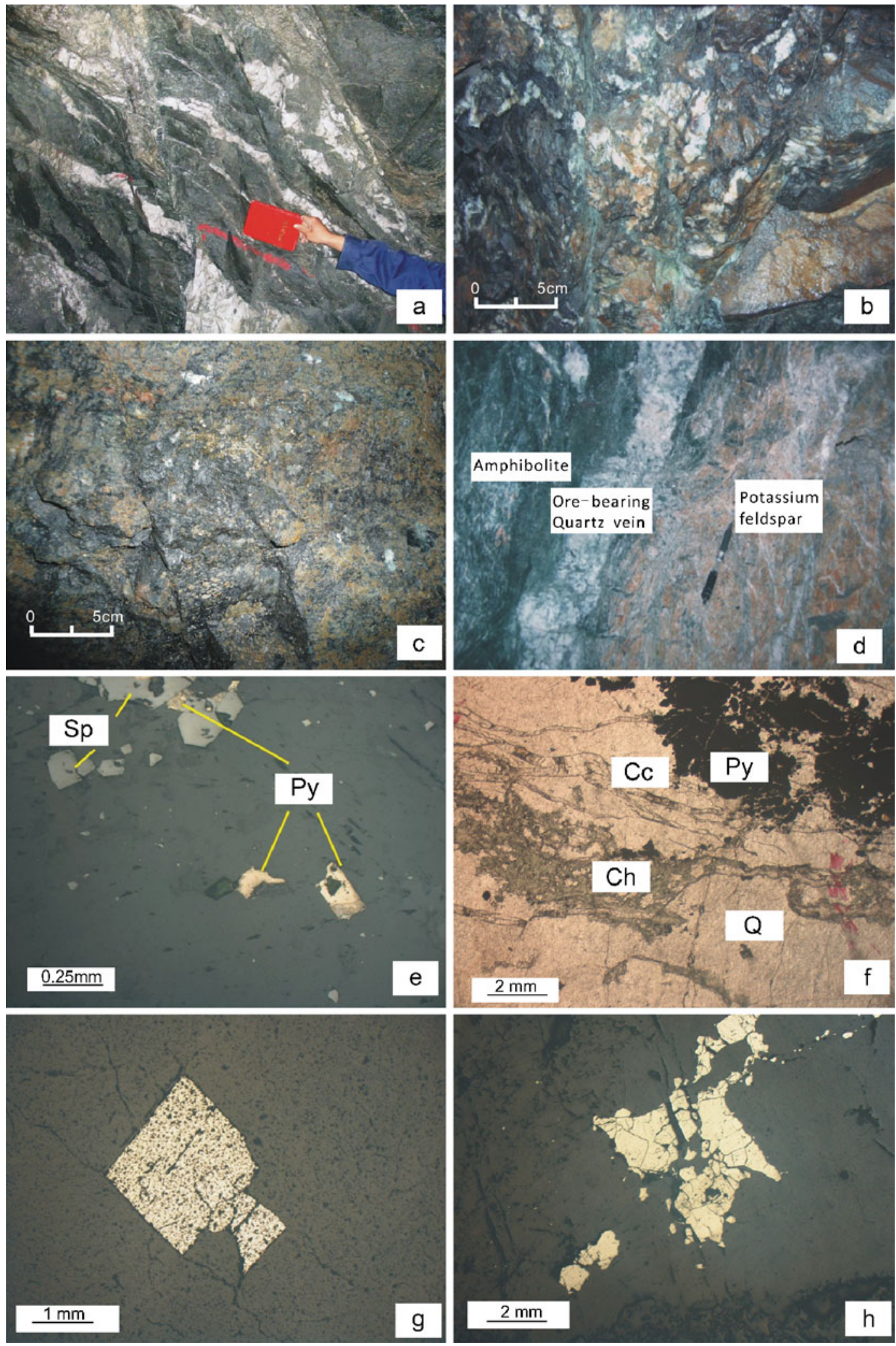

Figure 3. Photographs showing mineralisation characteristics of the Jiapigou gold belt, China (e, f, g and h are orthogonal polarisation photomicrographs). (a) Mineralised type of quartz vein; (b) mineralised type of disseminated ore (gold-bearing disseminated quartz); (c) mineralised type of alteration; (d) contact relationship of different alteration zones; (e) metallic minerals; (f) gangue minerals; (g) pyrite with euhedral-granular texture; (h) pyrite with xenomorphic and cataclastic structure; Py - pyrite, Sp - sphalerite, Cc - calcite, Ch - chlorite, Q - quartz. 

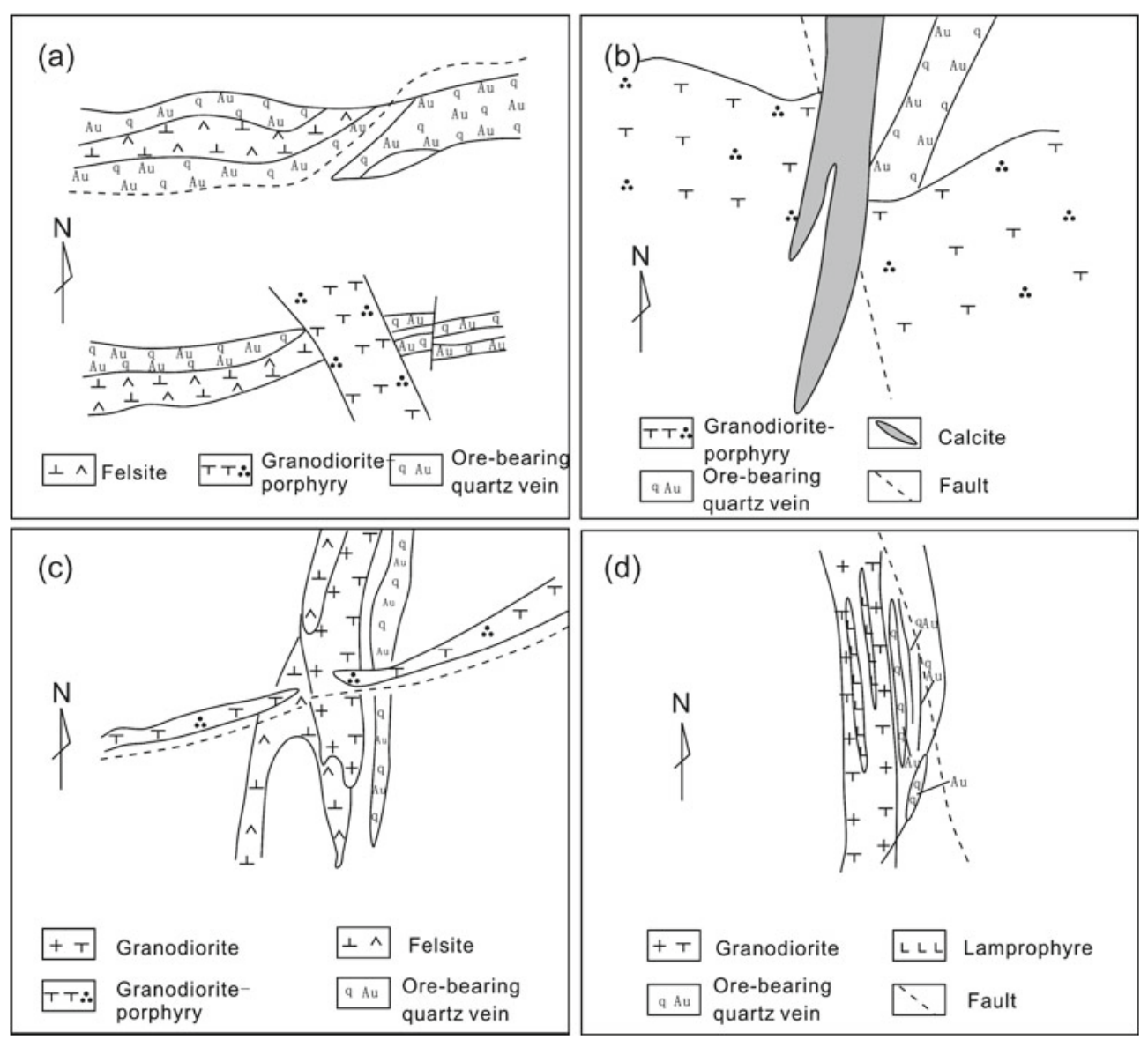

Figure 4. Sketch map showing the relationship among dikes, quartz veins and alteration zones in the Jiapigou gold belt (not to scale) ((a) Lishan deposit, (b) Sandaocha deposit, (c) Bajiazi deposit, and (d) Laoniugou deposit).

\subsubsection{Granite}

Samples of the Palaeoproterozoic granite are greyish-white to dark grey. Potassium feldspar $(45 \%)$, plagioclase $(20 \%)$, quartz $(30 \%)$ and biotite $(5 \%)$ are the major mineral components observed under the microscope; titanite, apatite, and magnetite are the minor minerals, and epidote and zircon are accessory minerals. In general, the granites are characterised by granoblastic textures.

Greyish-white to flesh red Mesozoic granite occurs as plutons along the northern portion of the WNW-trending Jiapigou Fault. Microscopic analyses revealed that plagioclase $(45 \%)$, potassium feldspar (25\%), quartz $(20 \%)$ and biotite $(5 \%)$ are the major mineral components and that the granites have porphyritic or gneissic textures.

\subsubsection{Amphibolite}

Wall-rock-amphibolites make up the subordinate rocks in the study area. The amphibolites are distributed in irregular shapes, such as islands or bands, due to the influence of dynamic compression. Samples are fulvous, and the major minerals include hornblende (65\%), plagioclase (25\%), quartz $(<10 \%)$ and chlorite (secondary mineral of hornblende), while minor minerals include apatite, titanite and magnetite. Crystalloblastic textures and massive structures are the main petrologic features of the amphibolites.

\section{Sample collection and analytical methods}

\subsection{Sampling}

Granite and metamorphic rocks occur widely within the Jiapigou gold belt. Fracture networks are generally observed near the contact between the granite and the metamorphic rock, and are preferentially intruded by ore-forming fluid, forming high grade gold-bearing quartz veins. The ores, granites and amphibolite are parallel or interweave with each other. A total of 21 samples were collected from different ore bodies, granite plutons and metamorphic wall rocks (amphibolite) in 
several of the largest ore deposits along the Jiapigou gold belt. To ensure that the rocks were not subject to weathering, all samples were collected from underground tunnels. The detailed sample surface locations are shown in figure 1.

All 21 samples were analysed for REE concentrations using ICP-MS. Two granite samples were analysed for $\mathrm{U}-\mathrm{Pb}$ dating by $\mathrm{LA}-\mathrm{ICP}-\mathrm{MS}$, and all quartz vein samples were studied for fluid inclusion characteristics. The names and classifications of the samples are as follows: four Palaeoproterozoic granite samples (JP18, JP46, JP68-1 and JP87), three Mesozoic granite samples (JP16, JP20 and JP4-1), seven wall-rock-amphibolite samples (3DC03, BG21, JL6D, JP42, JP85-1, SDC5D and 4DC11D), and seven gold-bearing quartz vein samples (EDG01, JP44-1, HG01, XXT01, BJZ06, XXT05 and JP71).

\subsection{Rare earth element analysis}

REE geochemical analyses were conducted at the Institute of Geophysical and Geochemical Exploration, Chinese Academy of Geological Sciences. Whole rock samples were crushed in a corundum jaw crusher (to 60 mesh). About $60 \mathrm{~g}$ was powdered in an agate ring mill to less than 200 mesh. The samples were then digested by $\mathrm{HF}+\mathrm{HNO}_{3}$ in Teflon bombs and analysed with an Agilent 7500a ICP-MS. The detailed sample-digesting procedure for the ICP-MS analyses of REEs was the same as described by Liu et al. (2008), and the analytical precision and accuracy was $0.1 \mathrm{mg} / \mathrm{kg}$. The 15 REEs comprise La, Ce, Pr, Nd, Sm, Eu, Gd, Tb, Dy, Ho, Er, Tm, Yb, Lu and Y. Chondritic values by Herrmann et al. (1971) were used for normalisation and modified for REE analysis.

\subsection{Geochronological analysis}

Zircons for LA-ICP-MS U-Pb dating were separated from samples JP20 and JP87. The zircon separation was carried out first by conventional magnetic and density techniques for the concentration of non-magnetic heavy fractions. Representative zircon grains were then picked out under a binocular microscope. The zircons were mounted on an epoxy mount and polished down to half section. The morphology and internal structures were recorded in transmitted and reflected light and in cathodoluminescence (CL) images to guide the LA-ICP-MS analysis. The CL imaging was carried out using a scanning electron microscope at the Chinese Academy of Geological Sciences, Beijing, China. The zircon LA-ICP-MS U-Pb analyses were performed on an Agilent 7500a ICPMS with a Geolas 2005 laser ablation sampler at the State Key Laboratory of Geological Processes and Mineral Resources, China University of Geosciences, Wuhan. Helium was applied as a carrier gas. Argon was used as the make-up gas and was mixed with the carrier gas via a T-connector before entering the ICP. Nitrogen was added to the central gas flow $(\mathrm{Ar}+\mathrm{He})$ of the Ar plasma to decrease the detection limit and improve precision. Each analysis incorporated a background acquisition of approximately 20-30 s (gas blank) followed by $50 \mathrm{~s}$ of data acquisition from the sample. Off-line selection and integration of background and analyte signals, and time-drift correction and quantitative calibration for the $\mathrm{U}-\mathrm{Pb}$ dating were performed using ICPMSDataCal (Liu et al. 2010). Zircon 91500 was used as the external standard for the $\mathrm{U}-\mathrm{Pb}$ dating and was analysed twice every five analyses. Time-dependent drifts of the $\mathrm{U}-\mathrm{Th}-\mathrm{Pb}$ isotopic ratios were corrected using a linear interpolation (with time) for every five analyses according to the variations of 91500 (i.e., 2 zircon $91500+$ 5 samples +2 zircon 91500) (Liu et al. 2010). The preferred $\mathrm{U}-\mathrm{Th}-\mathrm{Pb}$ isotopic ratios used for zircon 91500 are from Wiedenbeck et al. (1995). Concordia diagrams and weighted mean calculations were made using Isoplot/Ex-ver3 (Ludwig 2003).

\subsection{Fluid inclusion analysis}

The microthermometric study was carried out in the State Key Laboratory of Geological Processes and Mineral Resources, China University of Geosciences. Microthermometric determinations were made on doubly polished thin sections (about $100 \mu \mathrm{m}$ thick) using a LINKAM THMSG600 heating-freezing stage. The heating/freezing rate was generally $0.2-5^{\circ} \mathrm{C} / \mathrm{min}$, but was reduced to less than $0.2^{\circ} \mathrm{C} / \mathrm{min}$ near the phase transformation. The heating-freezing stage was calibrated using the standard of synthetic fluid inclusions produced by America FLUIDINC. Temperature errors are estimated at $\pm 0.5^{\circ} \mathrm{C}$ between $-120^{\circ} \mathrm{C}$ and $-70^{\circ} \mathrm{C}$ and $\pm 0.2^{\circ} \mathrm{C}$ between $-70^{\circ} \mathrm{C}$ and $500^{\circ} \mathrm{C}$. The salinities were expressed as wt. $\% \mathrm{NaCl}$ equivalent, and were calculated according to the freezing temperature and the equation provided by Bodnar (1993).

\section{Results}

\subsection{REE characteristics}

The measured REE concentrations are listed in table 1 and the chondrite-normalised curves are shown in figure 5 . 


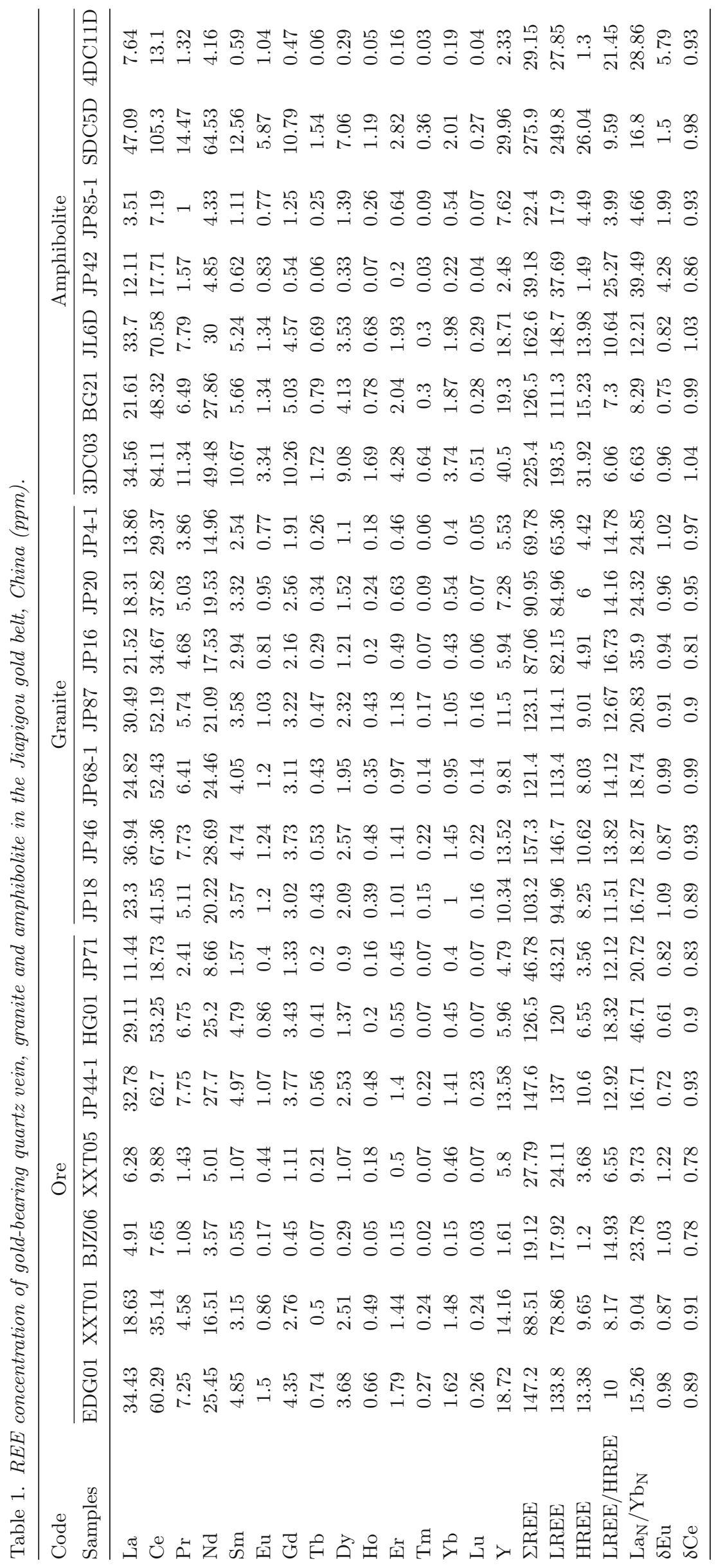



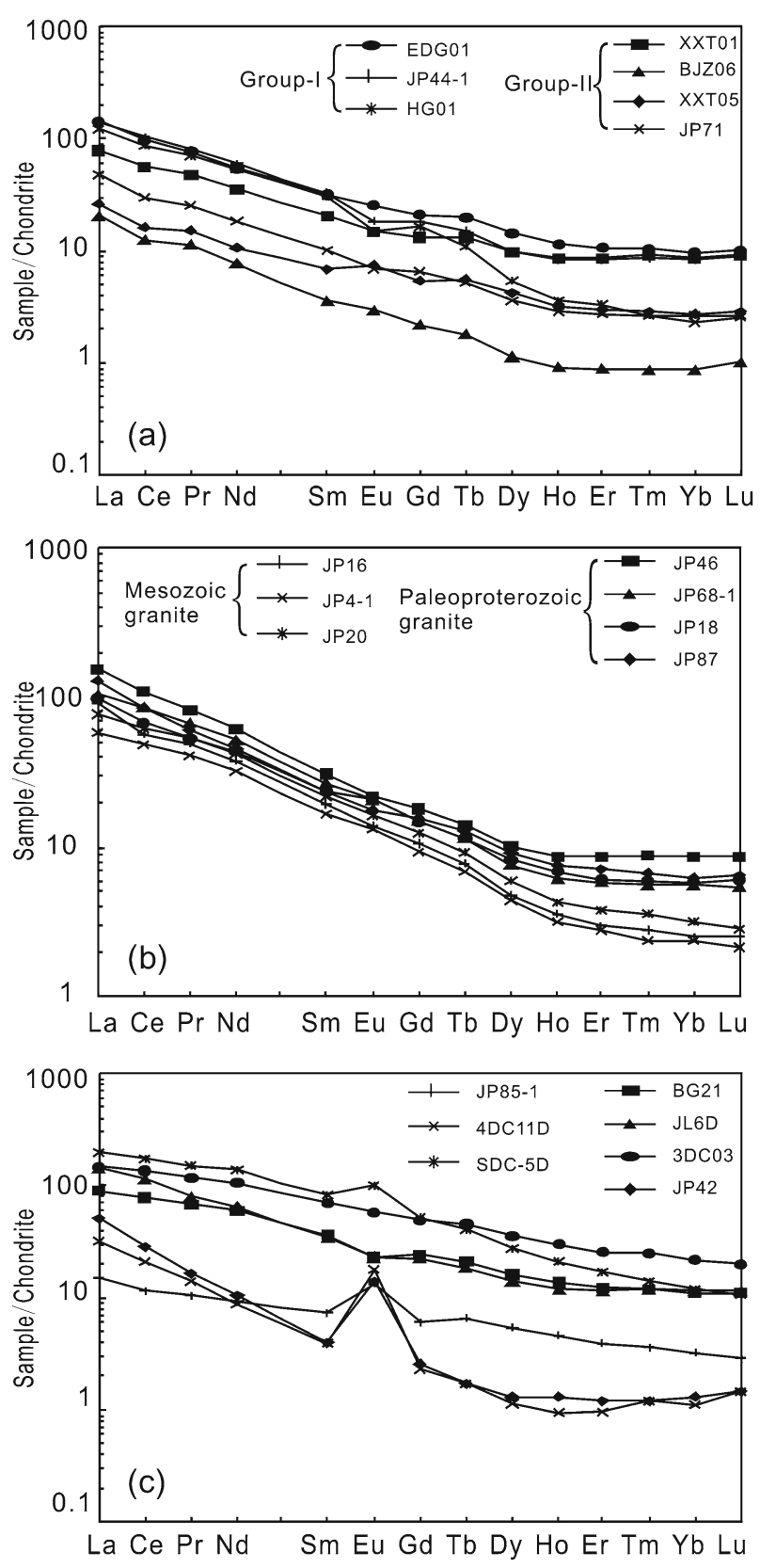

Figure 5. Chondrite normalised REE distribution patterns for (a) gold-bearing quartz veins, (b) granites and (c) amphibolites from the Jiapigou gold belt.

\subsubsection{Gold-bearing quartz veins}

Samples EDG01, JP44-1, HG01, XXT01, BJZ06, XXT05 and JP71 were collected from six different ore deposits in the Jiapigou gold belt. Although table 1 and figure 5(a) show high variations of $\mathrm{REE}$, the HREE concentrations differ only in a relatively narrow range for the ore body; $\Sigma \mathrm{REE}=$ 19.12-147.57 ppm, $\Sigma$ LREE $=17.92-136.97 \mathrm{ppm}$, $\Sigma$ HREE $=1.20-13.38 \mathrm{ppm}$ and LREE/HREE $=$ 6.55-18.32. The ore-bearing quartz vein samples could be divided into two groups, group-I and
group-II, based on the attitude of the quartz veins. Group-I veins are oriented WNW and represented by sample EDG01, JP44-1, and HG01, while group-II veins are oriented NNE-ENE and represented by samples XXT01, BJZ06, XXT05 and JP71. The $\Sigma$ REE values of group-I are greater than $100 \mathrm{ppm}$ and range between 126.50 and $147.57 \mathrm{ppm}$, whereas group-II has $\mathrm{RREE}$ values less than $100 \mathrm{ppm}$, ranging between 19.12 and $88.51 \mathrm{ppm}$. The REE concentrations of group-I are thus 2-7 times higher than those of groupII. Accordingly, the $\Sigma$ LREE (119.96-136.97 ppm) and LHREE (6.55-13.38 ppm) concentrations of group-I are generally higher than those of groupII $(\Sigma \mathrm{LREE}=17.92-78.86 \mathrm{ppm}, \Sigma \mathrm{HREE}=1.20$ $9.65 \mathrm{ppm})$, though the two groups overlap slightly. Furthermore, all samples in group-I show a distinctive negative Eu anomaly, while samples in groupII show a low negative or positive Eu anomaly; the average $\delta \mathrm{Eu}$ (The $\mathrm{Eu}$ anomaly is expressed in this contribution as $\delta \mathrm{Eu}=\mathrm{Eu}_{\mathrm{N}} /\left(\mathrm{Sm}_{\mathrm{N}} * \mathrm{Gd}_{\mathrm{N}}\right)^{1 / 2}$ and $\mathrm{Ce}$ anomaly is expressed as $\delta \mathrm{Ce}=\mathrm{Ce}_{\mathrm{N}} /\left(\mathrm{La}_{\mathrm{N}} * \mathrm{Pr}_{\mathrm{N}}\right)^{1 / 2}$.) values are 0.77 and 0.99 for group-I and groupII, respectively. These data show that the REE characteristics of the two groups are different to some extent. The REE concentrations of the samples depend heavily on the mineral composition, the temperature and pressure of mineralisation (Curtis and Schmitt 1979; Srinivasan et al. 1997) and the characteristics of the ore-forming fluids. As mentioned above, all the gold-bearing quartz veins found in the mineralised areas have similar mineralogical compositions. As shown in figure 6 and table 1 , the chondrite-normalised REE distribution patterns of all the samples belong to the LREE-enrichment type, and the two groups have LREE/HREE ratios that vary between 10.00-18.32 and 6.55-14.93, respectively, showing no significant fractionation in variations. This indicates that the two groups had a similar evolution process but originated from different sources.

\subsubsection{Granite}

Granite samples were collected from different plutons of the Jiapigou gold belt to ensure characteristic REE representations of the Palaeoproterozoic granite and Mesozoic granite. Samples JP18, JP46, JP68-1 and JP87 were collected from Palaeoproterozoic granite and samples JP16, JP20 and JP4-1 were collected from Mesozoic granite. The $\Sigma$ REE, $\Sigma$ LREE and $\Sigma$ HREE values of these granites are 69.78-157.32, 65.36-146.70 and 4.42$10.62 \mathrm{ppm}$, respectively (table 1 and figure $5 \mathrm{~b}$ ). The LREE/HREE values range between 11.51 and 16.73 . The $\delta \mathrm{Eu}$ values are $0.87-1.09$, with an average of 0.97 , and do not have a pronounced negative 

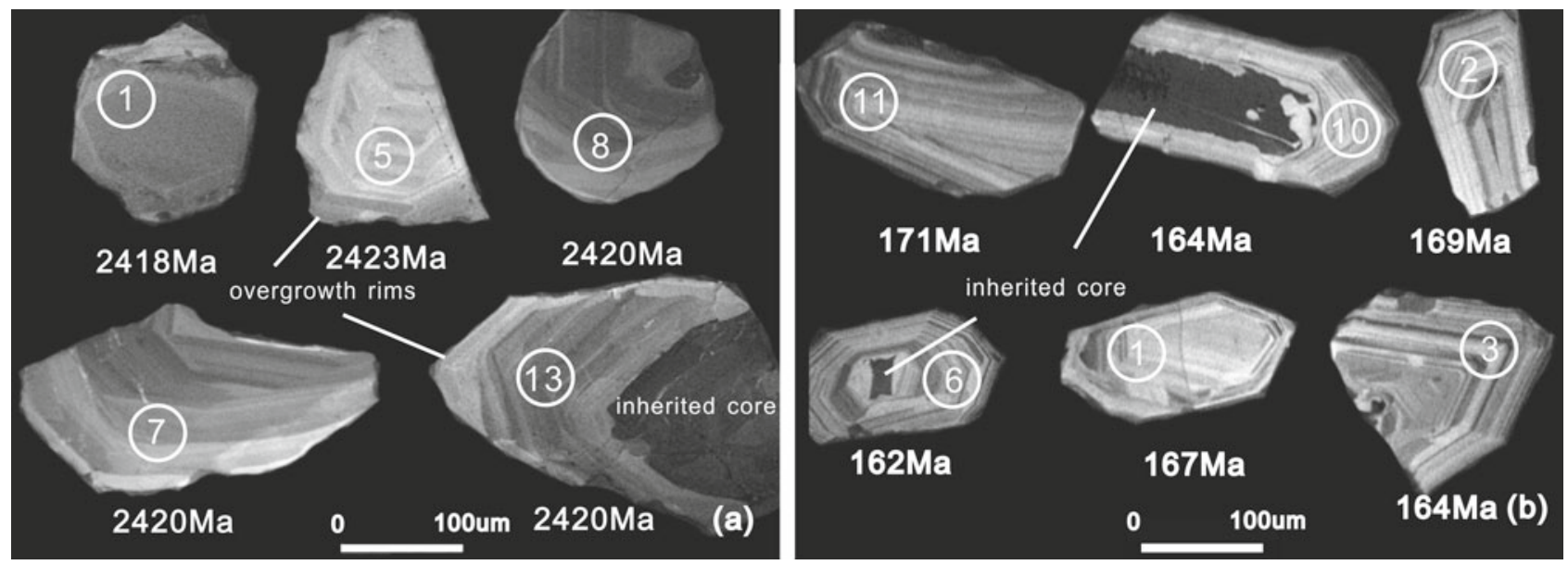

Figure 6. Representative cathodoluminescence (CL) images showing the morphology and internal textures of zircons from granite in the Jiapigou gold belt. CL images of zircons from (a) sample JP87 and (b) sample JP20. Descriptions of zircons are included in the text.

Eu anomaly. The $\delta$ Ce ranges between 0.81 and 0.99 and averages 0.92 with a low negative Ce anomaly.

In comparison, the REE, LREE and HREE concentrations of the Palaeoproterozoic granite are higher than those of the Mesozoic granite. The REE concentrations in the Palaeoproterozoic granites range from 103.2 to $157.32 \mathrm{ppm}$ (much higher than $100 \mathrm{ppm}$ ), the LREE concentrations are 94.96-146.70 ppm, and the HREE concentrations are 8.03-10.62 ppm. The REE concentrations in the Mesozoic granites are below $100 \mathrm{ppm}$ $(\Sigma \mathrm{REE}=69.78-90.95 \mathrm{ppm})$, while the LREE concentrations range between 65.36 and $84.96 \mathrm{ppm}$, and the HREE concentrations are between 4.42 and $6.00 \mathrm{ppm}$. These data clearly show that the REE, LREE and HREE concentrations of the Palaeoproterozoic granite and the Mesozoic granite differ greatly. The samples from the Mesozoic granite are characterised by higher LREE/HREE values and the highest $\mathrm{La}_{\mathrm{N}} / \mathrm{Yb}_{\mathrm{N}}$ values $(24.32-$ $35.9)$, reflecting strong fractionation between the LREE and HREE and depletion of the HREE. The REE patterns of the samples from the Palaeoproterozoic granite plutons show that they are right oblique types, rich in LREE while flat in HREE pattern, representing strong fractionation of LREE but only slight fractionation of HREE.

\subsubsection{Wall rock (amphibolite)}

Samples 3DC03, BG21, JL6D, JP42, JP85-1, SDC5D and 4DC11D were collected in or near the contact zone of ore bearing quartz veins and amphibolites. The REE concentrations are as follows: $\Sigma$ REE $=22.40-275.86 \mathrm{ppm}, \quad \Sigma \mathrm{LREE}=$ 17.90-249.82 ppm, and $\Sigma$ HREE $=1.30-31.92$ ppm. The LREE/HREE ratio is $3.99-21.45$ and
$\mathrm{La}_{\mathrm{N}} / \mathrm{Yb}_{\mathrm{N}}=4.66-39.49$, reflecting lower fractionation than the granite and the ore bearing quartz veins (table 1 and figure $5 \mathrm{c}$ ). The $\delta \mathrm{Eu}=0.75-$ 5.79 with an average value of 2.30 , showing distinctive positive Eu anomalies in samples JP42, JP851, SDC5D and 4DC11D, while samples 3DC03, BG21 and JL6D have slight negative Eu anomalies. The chondrite-normalised curves also have different ranges of $\Sigma R E E$ values, fractionation of LREE and HREE, and Eu anomalies. REE is not affected and migrated in the process of metamorphism; the REE characteristics mainly depend on the primary rock (Cullers et al. 1974; Lewis et al. 1998). The primary rock formations of the gold belt amphibolites composite are a combination of TTG rocks and tholeiite (Sun et al. 1996). Thus, the diversification of the REE characteristic in wall-rocks is reasonable. However, all the REE models display a negative slope, indicating a typical LREEenrichment type and no visible fractionation of the HREE.

\subsection{Zircon $\mathrm{U}-\mathrm{Pb}$ geochronology}

The $\mathrm{U}-\mathrm{Pb}$ isotope compositions of zircons from sample JP87 and JP20 are presented in table 2, and the CL images and concordant diagrams are shown in figures $6-8$.

\subsubsection{Sample JP87}

This sample is composed of Palaeoproterozoic granite collected from $400 \mathrm{~m}$ underground in the Sandaocha deposit. The zircon grains used for the LA-ICP-MS U-Pb analyses are mostly euhedral, transparent to semi-transparent, light brown or colourless, generally $100-200 \mu \mathrm{m}$ (some up to 


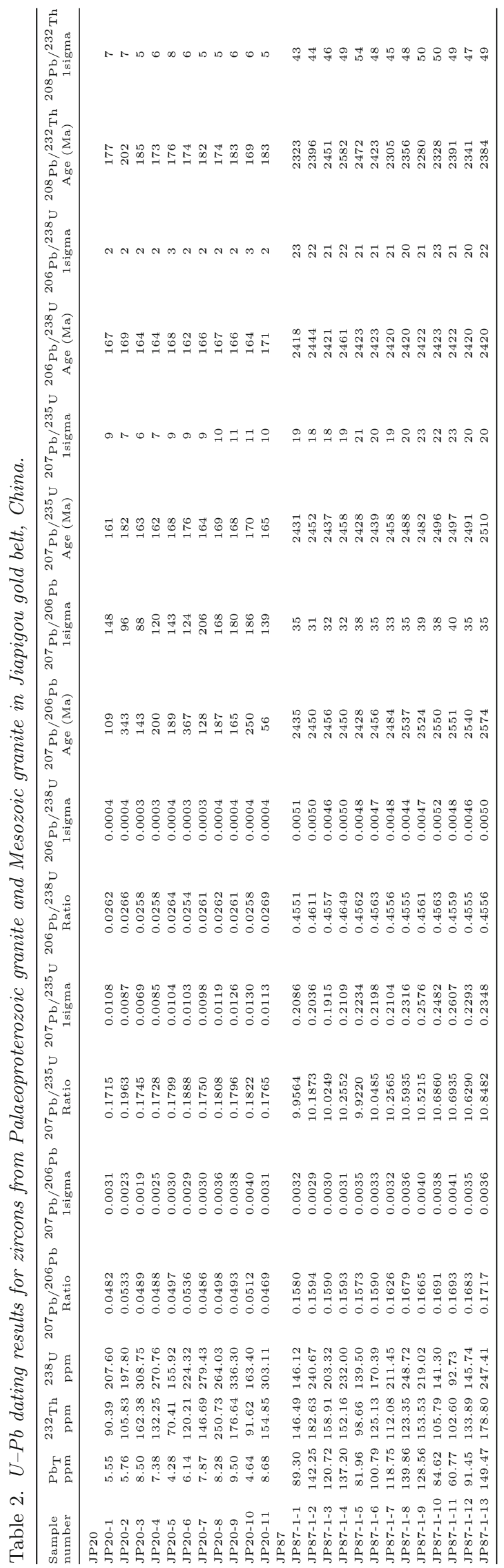

$200 \mu \mathrm{m}$ ) in length, and having length/width ratio close to 1 . Most of the zircon grains are rounded and fractured. The CL images indicate some inherited cores. In addition, some zircon grains have recrystallisation or overgrowth rims. A total of 13 analyses were conducted on 11 grains. U-Pb isotope compositions for zircons from this sample are presented in table 2 and in a Concordia diagram (figure 7). Uranium concentration ranges from 92.73 to $248.72 \mathrm{ppm}$, and Th ranges from 98.66 to $182.63 \mathrm{ppm}$. The $\mathrm{Th} / \mathrm{U}$ ratio is variable from 1.05 to 2.30 , much greater than 0.1 , and is consistent with an igneous origin. As shown in figure 7 , all 13 spots are concentrated in a small area on the Concordia curve and the ${ }^{206} \mathrm{~Pb} /{ }^{238} \mathrm{U}$ ages cluster in the range of 2461-2418 Ma, yielding a weighted average age of $2426.0 \mathrm{Ma}(\mathrm{MSWD}=0.33$ ). The ages of these zircons can be interpreted to represent the crystallisation age of the Palaeoproterozoic granite.

\subsubsection{Sample JP20}

Sample JP20 is comprised of Mesozoic granite collected from the Huangniling pluton $\left(42^{\circ} 52.211^{\prime} \mathrm{N}\right.$; $\left.127^{\circ} 33.342^{\prime} \mathrm{E}\right)$. The zircon grains from this sample are mostly euhedral, transparent to semitransparent, light brown or colourless, generally 50-300 $\mu \mathrm{m}$ in length, and have length/width ratio ranging between 2:1 and 10:1. Most of the zircon grains have fine prismatic shapes with abraded pyramids. The CL images indicate some inherited cores. Concentric oscillatory zoning is common in most crystals. A total of 11 analyses were conducted on 11 grains. The results are listed in table 2 and illustrated on a Concordia diagram in figure 8 . The uranium concentrations of sample JP20 range from 155.92 to $336.30 \mathrm{ppm}$, while Th ranges from 70.41 to $250.73 \mathrm{ppm}$. The Th/U ratios are variable between 0.90 and 2.02. In contrast to the metamorphic zircons, whose $\mathrm{Th} / \mathrm{U}$ ratios are generally lower than 0.1 (Vavra et al. 1996, 1999; Ubatto 2002; Yuan et al. 2009; Deng et al. 2010a), the zircons of samples JP87 and JP20 are characteristic of magmatic origin and have magmatogenic oscillatory zones. Therefore, the ages of these zircons can be interpreted to represent the crystallisation age of the Mesozoic granite. All data are distributed along the concordant line and the adjacent areas on the line and yielded $\mathrm{a}^{206} \mathrm{~Pb} /{ }^{238} \mathrm{U}$ weighted average age of 166.2 Ma (MSWD = 1.4).

\subsection{Fluid inclusions}

\subsubsection{Fluid inclusion types and occurrence}

All of the examined fluid inclusions are hosted by quartz crystals associated with oxides and 

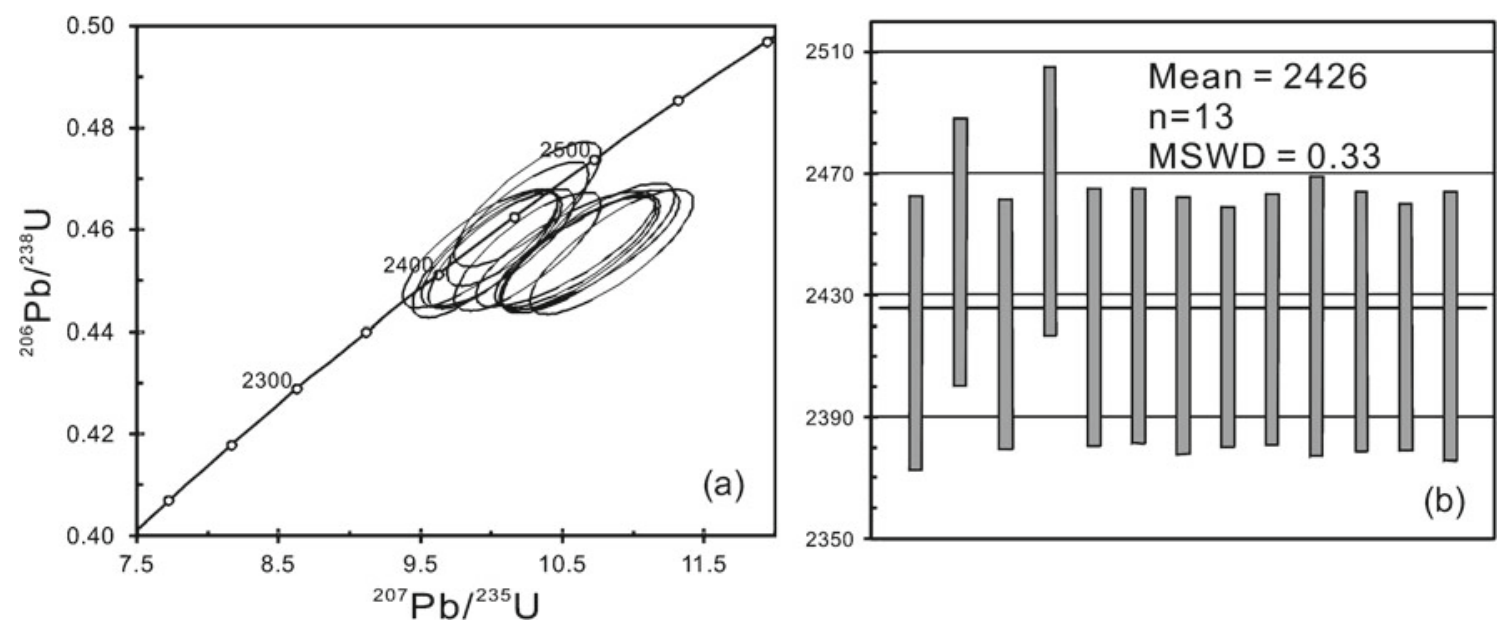

Figure 7. (a) Concordia diagram and (b) range of dates of LA-ICP-MS U-Pb zircon analytical results for granite sample JP87.
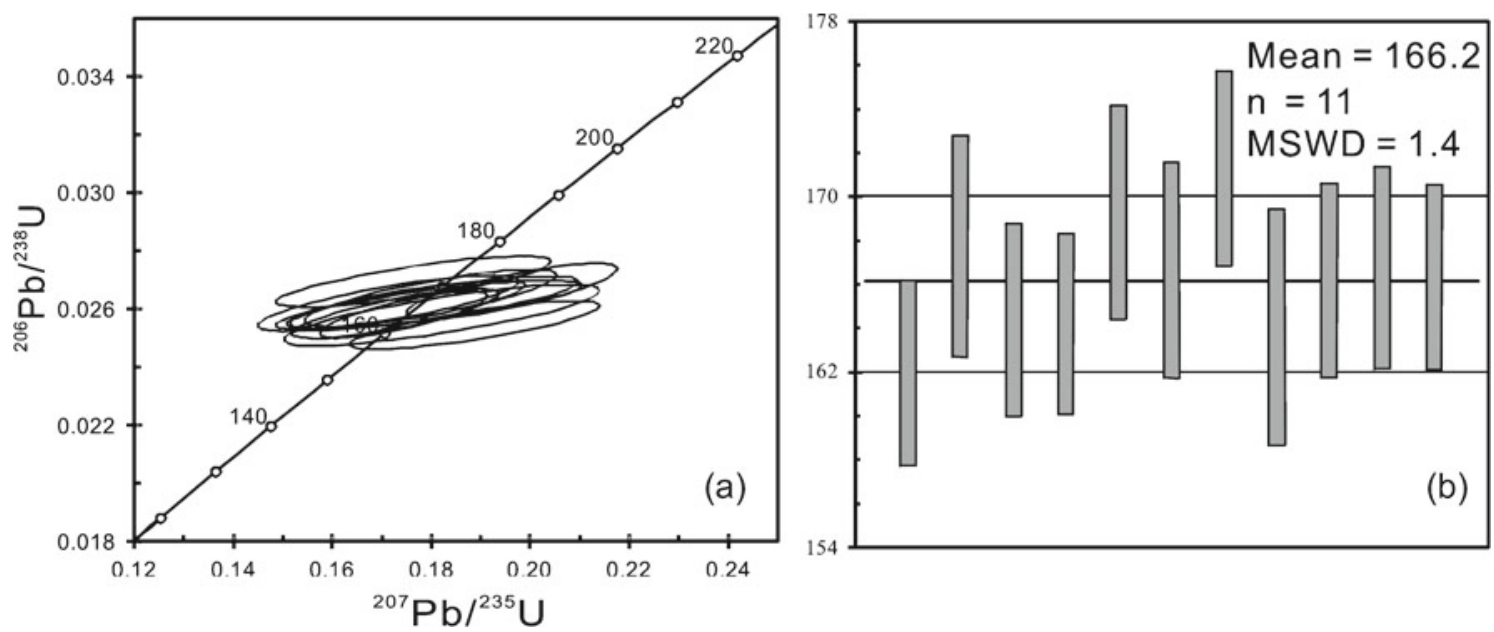

Figure 8. (a) Concordia diagram and (b) range of dates of LA-ICP-MS U-Pb zircon analytical results for granite sample JP20.

sulphides. Most of the fluid inclusions, occurring randomly distributed through the quartz crystals, as isolated fluid inclusions or grouped in clusters, appear to be primary inclusions. Petrographic examinations reveal that two types of fluid inclusions, with different composition and phase-transformations, are present in the quartz.

Type-I: $\mathrm{CO}_{2}$ fluid inclusions. Most of the fluid inclusions belonging to this type are two- or threephase at room temperature $\left(\mathrm{L}_{\mathrm{CO}_{2}}-\mathrm{L}_{\mathrm{H}_{2} \mathrm{O}}\right.$ or $\mathrm{V}_{\mathrm{CO}_{2}}-$ $\left.\mathrm{L}_{\mathrm{CO}_{2}}-\mathrm{L}_{\mathrm{H}_{2} \mathrm{O}}\right)$ and have round or oval shapes. Large size $(20-25 \mu \mathrm{m})$ fluid inclusions can be observed, although most are $3-15 \mu \mathrm{m}$. The carbonic phase occupies 20-80 vol.\% of the inclusion, and $\mathrm{V}_{\mathrm{CO}_{2}} /$ $\left(\mathrm{V}_{\mathrm{CO}_{2}}+\mathrm{L}_{\mathrm{CO}_{2}}\right)$ range from 10 to 30 vol. $\%$.

Type-II: Water-rich inclusions. These inclusions are two-phase aqueous inclusions that consist of vapour and liquid water at room temperature and can be divided into two subtypes, i.e., IIa and IIb subtypes, according to their vapour to liquid ratio. The IIa-subtype inclusions have $\mathrm{V}_{\mathrm{H}_{2} \mathrm{O}}=100 \%$, and the IIb-subtype inclusions have $\mathrm{V}_{\mathrm{H}_{2} \mathrm{O}} /\left(\mathrm{L}_{\mathrm{H}_{2} \mathrm{O}}+\mathrm{V}_{\mathrm{H}_{2} \mathrm{O}}\right)<30 \%$ by volume. The fluid inclusions have a variety of shapes (mainly oval, elongate and irregular) and are typically $4-15 \mu \mathrm{m}$ in size.

Type-I and type-II fluid inclusions are observed in the quartz from the Jinling, Xiaxitai and Erdaogou deposits, whereas only type-II fluid inclusions could be found in the quartz from the Bajiazi, Sidaocha and Beigou deposits, suggesting that the fluid system of the former deposits are $\mathrm{NaCl}-$ $\mathrm{H}_{2} \mathrm{O}-\mathrm{CO}_{2}$ solutions, while the latter deposits are $\mathrm{NaCl}-\mathrm{H}_{2} \mathrm{O}$ solutions. 


\subsubsection{Microthermometry}

The microthermometric characteristic of the different types of primary fluid inclusions are described below and the main microthermometric data obtained are summarised in table 3 .

Type-I fluid inclusions have $\mathrm{CO}_{2}$ eutectic temperatures of $-58.9^{\circ}$ to $-56.4^{\circ} \mathrm{C}$, which is lower than the eutectic homogenisation temperature of a pure $\mathrm{CO}_{2}$ inclusion $\left(-56.6^{\circ} \mathrm{C}\right)$ and indicates the presence of $\mathrm{N}_{2}$ or $\mathrm{CH}_{4} \cdot \mathrm{CO}_{2}$ clathrate compounds were observed in the process of heating and the disappeared temperatures are $3.5^{\circ}-9.2^{\circ} \mathrm{C}$. The $\mathrm{CO}_{2}$ homogenisation temperatures are $16^{\circ}-$ $30.9^{\circ} \mathrm{C}$ and usually range from $26.3^{\circ}$ to $30.3^{\circ} \mathrm{C}$. The homogenisation temperatures of this type of fluid inclusion are $310^{\circ}-429.8^{\circ} \mathrm{C}$. The fluid densities are estimated to be $0.61-0.96 \mathrm{~g} / \mathrm{cm}^{3}$, and the salinities are between 1.63 and 11.15 wt.\% $\mathrm{NaCl}$ equivalent.

Type-II fluid inclusions have eutectic temperatures of $-21.2^{\circ}$ to $-36.5^{\circ} \mathrm{C}$. The freezing temperatures were measured between $-1.3^{\circ}$ and $-20.7^{\circ} \mathrm{C}$, and the homogenisation temperatures are $94.7^{\circ}-$ $374.6^{\circ} \mathrm{C}$. The corresponding fluid densities and salinities were estimated to be in the ranges of $3.23-22.03 \mathrm{~g} / \mathrm{cm}^{3}$ and $2.24-22.85 \mathrm{wt} . \% \mathrm{NaCl}$ equivalent, respectively.

\section{Discussion}

\subsection{Epoch of gold mineralisation}

Statistical data on the attitudes of the main orecontrolling shear zones and gold veins in the Jiapigou gold belt show that the deposits can be divided into two types according to the trends of the gold-bearing quartz veins: (i) gold-bearing quartz veins distributed within the WNW-trending main ductile shear zone, and (ii) gold-bearing quartz veins within the NNE-ENE trending shear plane. The first type includes the Banmiaozi, Xiaobeigou, and Laoniugou deposits (figure 9). The second type

Table 3. Petrography and microthermometry for fluid inclusions in the Jiapigou gold belt, China.

\begin{tabular}{|c|c|c|c|c|c|c|c|}
\hline Deposit & Lithology & $\begin{array}{c}\text { Host } \\
\text { minerals }\end{array}$ & $\begin{array}{l}\text { Homogenization } \\
\text { temperatures }\left({ }^{\circ} \mathrm{C}\right)\end{array}$ & Fluid system & $\begin{array}{c}\text { Salinities } \\
\text { (wt\% } \mathrm{NaCl} \text { eqv) }\end{array}$ & $\begin{array}{l}\text { Fluid densities } \\
\qquad\left(\mathrm{g} / \mathrm{cm}^{3}\right)\end{array}$ & Reference \\
\hline Jinling & Ore & Quartz & $\begin{array}{l}\text { Type-I: } 352.8-429.8 \\
\text { Type-II: } 218.2-361.7\end{array}$ & $\mathrm{NaCl}-\mathrm{H}_{2} \mathrm{O}-\mathrm{CO}_{2}$ & $\begin{array}{l}4.2-10.7 \\
4.2-10.8\end{array}$ & $\begin{array}{l}0.61-0.65 \\
0.80-0.87\end{array}$ & Present research \\
\hline Xiaxitai & Ore & Quartz & $\begin{array}{l}\text { Type-I: } 352.8-429.8 \\
\text { Type-II: } 218.2-317.2\end{array}$ & $\mathrm{NaCl}-\mathrm{H}_{2} \mathrm{O}-\mathrm{CO}_{2}$ & $\begin{array}{l}1.63-11.15 \\
3.1-10.3\end{array}$ & $\begin{array}{l}0.61-0.85 \\
0.73-0.89\end{array}$ & Present research \\
\hline Erdaogou & Ore & Quartz & $\begin{array}{l}\text { Type-I: } 310-425.8 \\
\text { Type-II:153.2-338.8 }\end{array}$ & $\mathrm{NaCl}-\mathrm{H}_{2} \mathrm{O}-\mathrm{CO}_{2}$ & $\begin{array}{l}1.8-9.8 \\
4.6-11.6\end{array}$ & $\begin{array}{l}0.74-0.96 \\
0.54-0.81\end{array}$ & Present research \\
\hline Sandaocha & Ore & Quartz & Type-II: $104-323$ & $\mathrm{NaCl}-\mathrm{H}_{2} \mathrm{O}$ & $2.74-22.85$ & $0.80-1.11$ & Present research \\
\hline Bajiazi & Ore & Quartz & Type-II: $94.7-323$ & $\mathrm{NaCl}-\mathrm{H}_{2} \mathrm{O}$ & $3.3-9.6$ & $0.75-1.02$ & Present research \\
\hline Sidaocha & Ore & Quartz & Type-II: $143.5-272.2$ & $\mathrm{NaCl}-\mathrm{H}_{2} \mathrm{O}$ & $3.23-18.96$ & $0.78-1.02$ & Present research \\
\hline Beigou & Ore & Quartz & Type-II: $117.5-374.6$ & $\mathrm{NaCl}-\mathrm{H}_{2} \mathrm{O}$ & $4.18-22.03$ & $0.67-1.04$ & Present research \\
\hline Xiaxitai & Ore & Quartz & Type-I: $218.2-429.8$ & $\mathrm{NaCl}-\mathrm{H}_{2} \mathrm{O}-\mathrm{CO}_{2}$ & $4.2-10.8$ & $0.54-0.96$ & $\begin{array}{l}\text { Wang et al. }(2004) \\
\text { Cheng et al. }(1996)\end{array}$ \\
\hline Beigou & Ore & Quartz & $143.5-272.2$ & $\mathrm{NaCl}-\mathrm{H}_{2} \mathrm{O}$ & $3.3-9.6$ & $0.85-0.95$ & $\begin{array}{l}\text { Wang et al. (2004) } \\
\text { Deng et al. }(2003)\end{array}$ \\
\hline Erdaogou & Amphibolites & Quartz & $260.0-480.0$ & $\mathrm{NaCl}-\mathrm{H}_{2} \mathrm{O}$ & $36.5-54.8$ & $1.06-1.17$ & Dai et al. (2007) \\
\hline
\end{tabular}

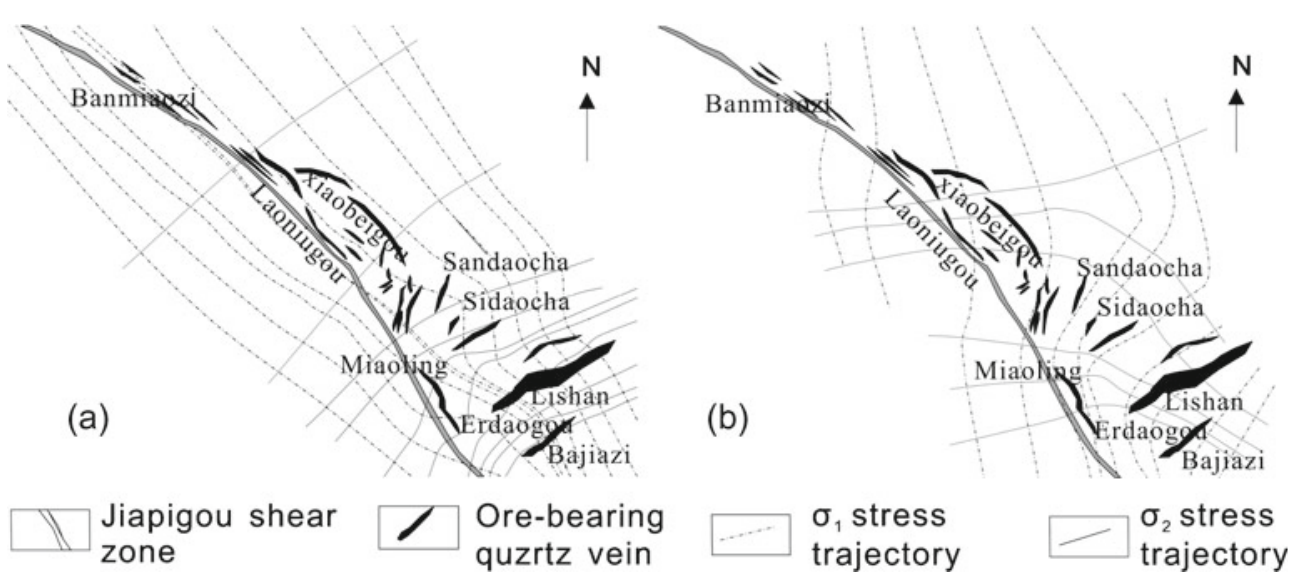

Figure 9. Maps showing the regional tectonic stress fields and distribution of the ore deposits in the Jiapigou gold belt. (a) Stress field in the early Palaeoproterozoic Era and (b) stress field in the Mesozoic Era. 
includes the Bajiazi, Lishan, Sidaocha and Sandaocha deposits (figure 9); these bodies are distributed as a string of needles and are controlled by a set of NNE-ENE trending ductile shears. The Erdaogou deposit occurs at the intersection of ENE and WNW striking shear zones. Similarly, the fluid inclusion data can be divided into two types obviously.

As mentioned in section 4, the REE characteristics of group-I are different from those of group-II. Moreover, it is clear that the Palaeoproterozoic granite and the Mesozoic granite have significantly different magma evolution processes and REE characteristics. The mobility and fractionation of REE in hydrothermal fluids are controlled by the fluid source, the availability of and the degree of complexation with ligands, the $\mathrm{pH}$ of the fluids and redox conditions (Gammons et al. 1996; Mayanovic et al. 2007). Similarly, the REE characteristics can reflect the rock's environment and conditions of formation, such as temperature, pressure, etc. (Haas et al. 1995; Anand and Balakrishnan 2011). The REE values of the Palaeoproterozoic granite and the gold-bearing quartz in group-I are $\Sigma$ REE $=121.40-157.32$ and 126.50-147.57 ppm, $\Sigma L R E E=94.96-146.70$ and 119.96-136.97 ppm, $\Sigma$ HREE $=8.03-10.62$ and 6.55-13.38 ppm, respectively. The REE values of the Mesozoic granites and the gold-bearing quartz in group-II are $\Sigma$ REE $=19.12-88.51$ and 69.78-90.95 ppm, $\Sigma$ LREE $=65.36-84.96$ and 17.92-78.86 ppm, HREE $=4.42-6.00$ and 1.20 $9.65 \mathrm{ppm}$, respectively. These comparisons clearly reflect the similar REE values of the Palaeoproterozoic granites and group-I gold-bearing quartz veins, as well as the similar REE values of the Mesozoic granites and group-II gold-bearing quartz veins (figure 10). To emphasise their similar characteristics, granite-normalised REE patterns of gold-bearing quartz of group-I and group-II were employed. The average REE concentrations of

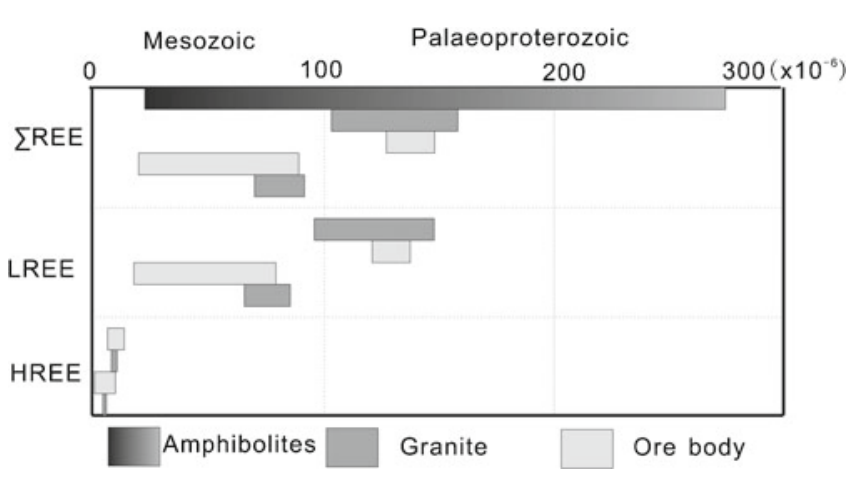

Figure 10. Chemical variation profile in REE (ppm) of amphibolites, granites and gold-bearing quartz veins.
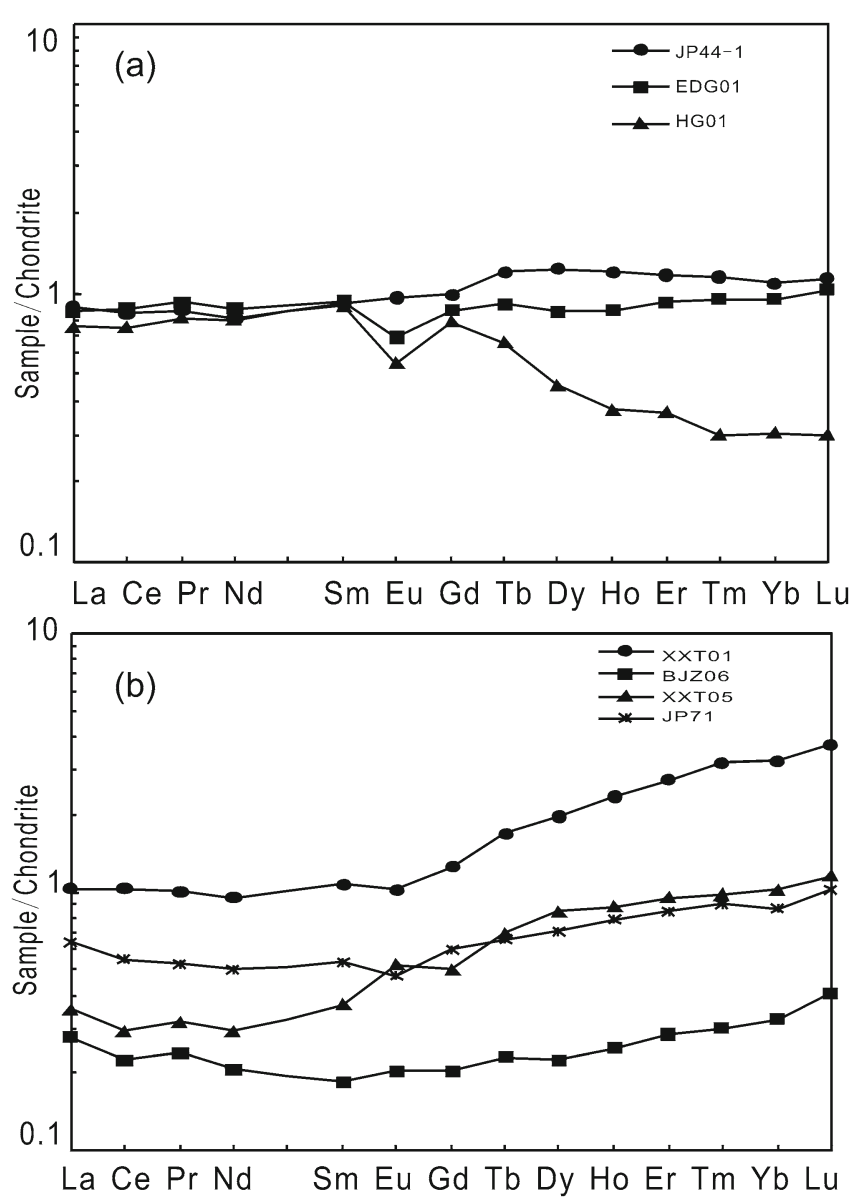

Figure 11. Granite-normalised REE distribution patterns for gold-bearing quartz veins. (a) Earlier gold-bearing quartz veins (group-I). The average granite REE concentrations of JP18, JP46, JP68-1 and JP87 are used as the standard values. (b) Later gold-bearing quartz veins (group-II). The average granite REE concentrations of JP16, JP20 and JP4-1 are used as the standard values.

the Palaeoproterozoic granite samples JP18, JP46, JP68-1 and JP87 are used to normalise group$\mathrm{I}$, and the average REE concentration of samples JP16, JP20 and JP4-1 are used to normalise groupII. On the whole, the quartz patterns of groupI have sample/granite ratios that are very close to 1 (figure 11a). It is likely that (i) the orebearing hydrothermal solution of the earlier quartz veins was closely related to (or mainly resulting from) the Palaeoproterozoic granitic magma, and (ii) the earlier gold-bearing quartz veins have not been modified or superimposed by late magmatic hydrothermal activity. Nevertheless, in detail, one sample (HG01) shows distinct HREE depletion and two samples (JP44-1 and HG01) show negative Eu anomalies compared to the granite; this is caused by the greater stability of LREE than HREE (Mayanovic et al. 2009) because the elements of $\mathrm{Eu}$ and HREE are inclined to undergo activation and migration when the physico-chemical parameters 

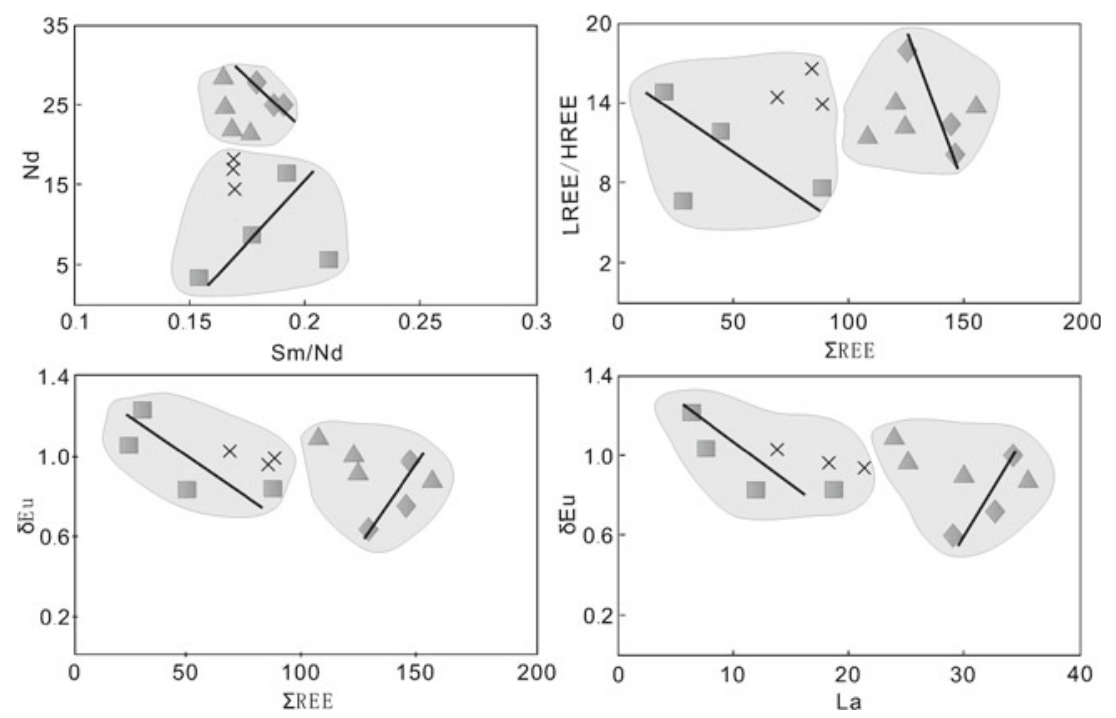

Figure 12. Bivariate graphic of REE characteristics of the Jiapigou gold belt, China. $\triangleleft$ : Earlier gold-bearing quartz vein; ㅁ: Later gold-bearing quartz vein; $\Delta$ : Palaeoproterozoic granite; $\times$ : Mesozoic granite.

are changed (Henderson 1984). The same observation and conclusion can be made for the quartz in group-II (the later quartz veins) and the Mesozoic granites (figure 11b) even though the values vary around 1 . By using a correlating concentration of two or more trace elements in the mineralisation system to establish the trace elements covariance diagram, we can interpret the formation process of the rock body and the genetic relationship between the different rock bodies (Henderson 1984). In this study, oEu-La, LREE/ HREE- $\Sigma$ REE, $\sigma E u-\Sigma R E E$ and $\mathrm{Sm} / \mathrm{Nd}-\mathrm{Nd}$ were chosen to plot the covariance diagram (figure 12), which clearly shows that the ore-bearing quartz veins of group-I plot nearly in the same region as Palaeoproterozoic granites. A similar relationship exists for the group-II gold-bearing quartz veins and the Mesozoic granites. Moreover, the two groups have different evolutionary trends. These observations provide evidence that the Jiapigou gold belt experienced multi-stage mineralisation related to granitic magmatism in the Palaeoproterozoic and the Mesozoic, and that the two stages of mineralisation are mutually independent.

According to the deposit geological and REE geochemical analyses, we propose that there were two periods of gold mineralisation in the Jiapigou gold belt that occurred in response to magmatism in the Palaeoproterozoic Era and the Mesozoic Era.

\subsection{Origin of ore-forming fluids}

The chondrite-normalised REE patterns of the gold-bearing quartz veins and granites have similar characteristics. A main feature of all the REE pattern curves is a negative slope with a slight Eu anomaly, suggesting that plagioclase fractionation only played a minor role during magma evolution, and that the partial melting processes played a dominant role in the rock formation. Because of the characteristics of the source materials (Tan et al. 2006; Deng et al. 2010b, 2011) or the existence of sulphide in the ore-forming fluid and the ore body (Pack et al. 2004; Xu et al. 2006), the total amount of REE in the ore bearing quartz vein and granite is low. Moreover, the $\Sigma$ REE values of the ore bearing quartz veins and granite samples are in the same range and have the same peak values, i.e., 19.12-147.57 and 69.78-157.32 ppm, respectively. However, the lowest value for the ore bearing quartz vein samples is far lower than that for the granites and is similar to the lowest value obtained for the wall rock (22.40 ppm). These data suggest that the REE activation and migration occurred mainly along the contact zone between the ore bodies and the granite, and only somewhat between the ore bodies and the wall rocks. In addition, the $\delta \mathrm{Eu}$ values of the altered wall rocks show a clear positive Eu anomaly, in contrast to the ore bodies. This result also confirms that there was no strong activation and migration between the ore bodies and the altered wall rock.

In comparing the $\delta \mathrm{Eu}$ characteristics of the gold-bearing quartz veins with the amphibolites, the $\delta \mathrm{Eu}$ values of the group-I gold-bearing quartz veins (earlier gold-bearing quartz veins) are 0.610.98 with an average value of 0.78 and a clear negative anomaly, while group-II gold-bearing quartz veins (later gold-bearing quartz veins) have $\delta \mathrm{Eu}$ values of $0.87-1.22$, an average value of 1.04 and a low positive $\mathrm{Eu}$ anomaly. The $\delta \mathrm{Eu}$ values of 
the later gold-bearing quartz veins are similar to those of the wall rock. Moreover, the granitenormalised REE diagrams show HREE depletion in figure 11(a) but enrichment in figure 11(b) and sample/granite ratios of both about 1 and slightly less than 1 . These data may indicate that the later gold-bearing quartz veins have undergone stronger metamorphic hydrothermal contamination than the earlier gold-bearing quartz veins.

Fluid inclusion petrography and microthermometry were conducted in this study, and some of the data have been reported by Wang et al. (2004) and Cheng et al. (1996) (table 3). The homogenisation temperatures of the gold-bearing quartz fluid inclusions were $94.7^{\circ}-429.8^{\circ} \mathrm{C}$. The fluid densities were estimated to be between 0.54 and $1.11 \mathrm{~g} / \mathrm{cm}^{3}$, with salinities between $1.63 \%$ and $22.85 \% \mathrm{NaCl}$ eqv. The Jinling, Xiaxitai and Erdaogou deposits were $\mathrm{NaCl}-\mathrm{H}_{2} \mathrm{O}-\mathrm{CO}_{2}$ system, while the Bajiazi, Sidaocha and Beigou deposits were $\mathrm{NaCl}-\mathrm{H}_{2} \mathrm{O}$ system. Both of them are characterized by variable temperatures, middle densities, and low salinities. However, the homogenisation temperatures of the altered rock quartz fluid inclusions are $260^{\circ}-480^{\circ} \mathrm{C}$, and the fluid densities are estimated to be between 1.06 and $1.17 \mathrm{~g} / \mathrm{cm}^{3}$, with salinities between $36.5 \%$ and $54.8 \% \mathrm{NaCl}$ eqv., was middle to high temperatures, high densities and salinities $\mathrm{NaCl}-\mathrm{H}_{2} \mathrm{O}$ solutions. Sun et al. (2000) determined bulk isotopic compositions of oxygen and hydrogen in the Jiapigou gold belt. $\delta \mathrm{D}$ was measured directly from inclusion waters, while $\delta^{18} \mathrm{O}$ was determined in the gold-bearing quartz. They observed $\delta \mathrm{D}$ values of $-92 \%$ to $-70 \%$ and $\delta^{18} \mathrm{O}$ values of $0.5 \% 0-5.5 \%$, differ from typical compositions of juvenile $(\delta \mathrm{D}=$ $-50 \%$ to $-80 \%$; $\delta \mathrm{O}=6 \% 0-10 \%$ ) and metamorphic $(\delta \mathrm{D}=-20 \%$ to $-70 \% 0 ; \delta \mathrm{O}=5 \% 0-25 \%$ ) water but are much closer to the composition of magmatic water. The volatile species identified in bulk fluid inclusion analyses are $\mathrm{H}_{2} \mathrm{O}, \mathrm{CO}_{2}, \mathrm{CH}_{4}, \mathrm{~N}_{2}$ and $\mathrm{H}_{2}, \mathrm{H}_{2} \mathrm{O}, \mathrm{CO}_{2}$ and $\mathrm{N}_{2}$ are relatively dominant, and $\mathrm{H}_{2} \mathrm{O}$ and $\mathrm{CO}_{2}$ are the most important volatile species. $\mathrm{CO}_{2}$ is considered to be favourable for gold enrichment and transportation in ore fluids (Heinrich 2007) and the $\mathrm{CH}_{4}$ indicates that the ore fluids are in a reduced state. However, $\mathrm{CO}_{2}$ and $\mathrm{CH}_{4}$ were not generally detected in the altered rock type, which also suggests that the ore-forming fluids resemble magmatic rather than metamorphic fluid.

Based on the geochemical analyses above, we conclude that the ore-forming hydrothermal solutions of the Jiapigou gold belt were mainly of juvenile origin, namely, the granitic magmas, and were partially influenced by metamorphic fluids, especially during the Mesozoic gold mineralisation.

\subsection{Age of gold mineralisation}

The timing of the gold deposits in the Jiapigou area is extremely controversial, with interpreted ages ranging from the Neoarchaean-Palaeoproterozoic, 2475-2469 Ma (Sun 1995; Cheng et al. 1996), the Indo-Chinese epoch of the Mesozoic, $204 \mathrm{Ma}$ (Luo et al. 2002), to the Yanshannian epoch of the Mesozoic, 170-160 Ma (Wang 1994; Sun and Feng 1997; Dong et al. 1999; Shen et al. 1999). There are also several interpretations of multi-phase mineralisation, 3000-2800 Ma, 2700-2500 Ga, 2000-1800 Ma, 500-300 Ma, 230-130 Ma (Sun 2003; Zhao et al. 2006; Xie et al. 2008). The primary reasons for the differing ages are the interpretation that the ore-forming fluids were either magmatic or metamorphic hydrothermal fluids and the focus of the studies on analysing different rock types, including igneous rocks (granite, granodiorite, granite porphyry), metamorphic rocks (amphibolite, gneiss), or different phase quartz veins. These differences have led to the various conclusions about the metallogenic epoch, especially in deposits with compound origins, such as the deposit in Jiapigou gold belt.

For example, the Jiapigou deposits were considered to be typical late-Archaean lode-gold deposits by Sun (1995) and Cheng et al. (1996), primarily because they are hosted in late Archaean rocks and are similar to those in Zimbabwe, central Canada and Western Australia (Goldfarb et al. 2001; Groves et al. 2003). This appeared to be confirmed when dated zircons from gold-bearing quartz veins gave an upper intercept $\mathrm{U}-\mathrm{Pb}$ age of 2475 Ma. However, Phanaerozoic dikes in the region contain xenocrystic zircons or inherited cores (Miao et al. 2005) from the late Archaean host rocks; thus, the ages of these zircons are consistent with those from gold-bearing quartz veins as reported by Sun (1995) and Cheng et al. (1996). It is more likely that the zircons from the quartz veins, which were considered to be hydrothermal in origin by these authors, were trapped from the host rocks.

Sun and Feng (1997) and Li et al. (2004) proposed that the Jiapigou gold deposits were formed during the Triassic period (161-167 Ma), mainly based on the zircon LA-ICP-MS U-Pb dates on quartz from the Bajiazi and Erdaogou gold deposits and the sericite $\mathrm{Ar}-\mathrm{Ar}$ dates on mylonites within an alteration zone in the Bajiazi gold deposit. However, as discussed earlier in this paper, multiple mineralisation events occurred in this area, while the Bajiazi gold deposit and the partial Erdaogou gold deposit were formed in a single ore-forming period. Therefore, these ages do not fully represent the mineralisation age of the Jiapigou gold belt. We suggest that special 
caution must be taken when dating gold deposits with multiple mineralisation events and it is necessary to determine the stage of gold mineralisation and origin of the ore-forming fluids before performing the dating.

In this research, the results of zircon $\mathrm{LA}-\mathrm{ICP}-$ MS U-Pb dating show that the age of the Palaeoproterozoic granite is $\sim 2426.0 \mathrm{Ma}$, and the age of the Mesozoic granite is $\sim 166.2$ Ma. Because the characteristics of the REE geochemistry of these granites, as well as the spatial relationships are consistent with those of gold-bearing quartz veins, the $2426.0 \mathrm{Ma}$ and 166.2 Ma ages can be considered to be the maximum ages of two separate periods of gold mineralisation. These two periods are close to the $\mathrm{Rb}-\mathrm{Sr}$ isochron dates of $2475 \mathrm{Ma}$ on water extracted from fluid inclusions in the quartz of gold-bearing quartz veins ( $\mathrm{Li}$ et al. 1996) and the $\mathrm{K}-\mathrm{Ar}$ dates of $161 \mathrm{Ma}$ on potassium feldspar extracted from gold-bearing quartz diorite porphyrite (Li et al. 2004).

In summary, our new LA-ICP-MS data, combined with published data from the literature, indicate that the gold mineralisation of the Jiapigou gold belt first took place during the Palaeoproterozoic Era (maximum age $\sim 2426.0 \mathrm{Ma}$ ). The Yanshanian gold mineralisation event (maximum age $\sim 166.2 \mathrm{Ma}$ ) may also have had a major effect on the ore bodies of the Jiapigou gold belt, and this led to new gold mineralisation as well as redistribution of the Palaeoproterozoic ore bodies.

\subsection{Ore-forming model}

By way of geotectonic and regional structure of the Jiapigou gold belt, Deng et al. (2009) proposed that the Jiapigou region, located on the northeastern edge of the NCC, experienced at least two major phases of tectonism. In our work, large numbers of conjugate joints, tensional joints, faults and quartz veins were measured and analysed in the eight largest deposit in the gold belt. These data also support the conclusion that this area has undergone two stress regimes (figure 9): in the earlier phase of tectonic stress, $\sigma_{1}$ was oriented to the northwest, while in the second phase, it was oriented northeast, with a minor area of northwest orientation in the northwest section of the Jiapigou shear zone. The change in tectonism can explain why the quartz veins in deposits close to the main shear zone (e.g., Beigou, Erdaogou and Miaoling deposits) oriented WNW while those far from the shear zone (e.g., Lishan, Bajiazi, Sandaocha and Sidaocha deposits) have NNE-ENE orientations. As a result of the considerable rotation of $\sigma_{1}$, early pyrite grains show hypautomorphic-xenomorphic granular textures (figure $3 \mathrm{~h}$ ), while the younger formed pyrite grains show fine automorphic granular textures (figure $3 \mathrm{~g}$ ).

Based on the REE, fluid inclusions, geochronology, and ore geology analyses, we conclude that the Jiapigou gold belt was formed in two stages (figure 13):

In stage 1 , in the early Palaeoproterozoic Era, activity on an old basement fault led to the formation of the Jiapigou shear zone (Li et al. 2004) and formed large numbers of WNW-trending foliations. The intrusion of the granitic magma later $(\sim 2426.0 \mathrm{Ma})$ resulted in the formation of the Banmiaozi, Xiaobeigou, Laoniugou, Miaoling and Erdaogou deposits.

In stage 2, in the Triassic, large-scale sinistral strike-slip displacements on the NE-trending Huifahe and Liangjiang Faults resulted from the collision and subduction of the Pacific plate beneath the Eurasian plate (Deng et al. 2009). The Jiapigou Fault was folded and a series of radial NNE and NE-ENE-trending joints and



Figure 13. Metallogenic model of the Jiapigou gold belt, China. (a) First ore-forming stage and (b) second ore-forming stage. 
fractures were derived near the hinge zone. In the late Middle Triassic ( 166.2 Ma), mantle fluids derived from the intensive tectonic activity, extracted the gold from the wall rocks (TTG, greenstone) and remelted the wall rocks to form gold-rich granitic magma and intruded into the NNE-ENE trending fractures, leading to gold mineralisation. The main gold-bearing quartz veins in the Sandaocha, Sidaocha, Lishan and Bajiazi deposits were formed in this stage.

\section{Conclusions}

- The gold-bearing quartz veins in the Jiapigou gold belt can be divided into two stages, similar to the granites in this area. These stages indicate that the Jiapigou gold belt underwent two independent stages of gold mineralisation.

- Ore-forming fluids of the Jiapigou gold belt were mainly derived from magmatic hydrothermal fluids and were contaminated by metamorphic hydrothermal fluids. The quantity of metamorphic solution fluids increased during the Yanshannian epoch.

- The geochronology data of granites associated with gold mineralisation show that the age of Palaeoproterozoic granite is $\sim 2426.0 \mathrm{Ma}$, while the age of the Mesozoic granite is $\sim 166.2 \mathrm{Ma}$. These ages can be interpreted as the maximum ages of the two periods of gold mineralisation.

- The WNW-trending ore bodies were formed in the early Palaeoproterozoic as a result of geological deformation of the old basement, while the NNE-ENE-trending ore bodies were formed in the late Middle Triassic (Yanshanian stage Mesozoic) due to the large-scale sinistral strikeslip displacements of the Huifahe and Liangjiang Faults.

\section{Acknowledgements}

The authors would like to express sincere thanks to Dr Paul Eizenhöfer of Hongkong University, Prof. Jun Deng and Liqiang Yang of CUGB and Huihui Li for their encouragement and support. They also gratefully acknowledge the anonymous reviewers for their detailed reviews and constructive suggestions. The research is supported by the National Science Foundation of China (No. 40872068, 40872141, 41172088).

\section{References}

Anand R and Balakrishnan S 2011 Geochemical and Sm$\mathrm{Nd}$ isotopic study of titanite from granitoid rocks of the eastern Dharwar craton, southern India; J. Earth Syst. Sci. 120(2) 237-251.

Bodnar R J 1993 Revised equation and stable for determining the freezing point depression of $\mathrm{H}_{2} \mathrm{O}-\mathrm{NaCl}$ solutions; Geochim. Cosmochim. Acta 57 683-684.

Cheng Y M, Li J J and Shen B F 1996 Metallogenic and ore prospecting models of greenstone belts gold deposits in Southern Jilin Province and Northern Liaoning Province of China (Beijing: Seismological Press), pp. 87-91.

Cullers R L, Yeh L T and Chaudhuri S 1974 Rare earth elements in Silurian pelitic schists from N.W. Maine; Geochim. Cosmochim. Acta 38 389-400.

Curtis D B and Schmitt R A 1979 The petrogenesis of L-6 chondrites: Insights from the chemistry of minerals; Geochim. Cosmochim. Acta 43 1091-1103.

Dai J Z, Wang K Y and Cheng X M 2007 Geochemical features of ore-forming fluids in the Jiapigou gold belt, Jilin province; Acta Petrological Sinica 23 21982206 .

Deng J, Yang L Q, Sun Z S, Wang J P, Wang Q F, Xin H $\mathrm{B}$ and Li X J 2003 A metallogenic model of gold deposits of the Jiaodong granite-greenstone belt; Acta Geologica Sinica 77(4) 537-546.

Deng J, Wang Q F, Wan L, Yang L Q, Zhou L and Zhao J 2008 Random difference of the trace element distribution in Skarn and Marbles from Shizishan Orefield, Anhui Province, China; J. China University of Geosci. 19 319-326.

Deng J, Yang L Q and Gao B F 2009 Fluid evolution and metallogenic dynamics during tectonic regime transition: Example from the Jiapigou gold belt in northeast China; Resour. Geol. 59 142-154.

Deng J, Wang Q F, Yang S J, Liu X F and Zhang Q Z 2010a Genetic relationship between the emeishan plume and the bauxite deposits in Western Guangxi, China: Constraints from $\mathrm{U}-\mathrm{Pb}$ and $\mathrm{Lu}-\mathrm{Hf}$ isotopes of the detrial zircons in bauxite ores; J. Asian Earth Sci. 37 412424.

Deng J, Wang Q F, Yang L Q, Wang Y R, Gong Q J and Liu H 2010b Delineation and exploration of geochemical anomalies using fractal models in the Heqing area, Yunnan Province, China; J. Geochem. Explor. 105(3) 95-105.

Deng J, Wang Q F, Xiao C H, Yang L Q, Liu H, Gong Q J and Zhang J 2011 Tectonic-magmatic-metallogenic system, Tongling ore cluster region, Anhui Province, China; Int. Geol. Rev. 53(5-6) 449-476.

Dong D G, Kang B and Bo J R 1999 Metallogenic evolution and time of the Jiapigou gold-concentrated area; Geol. Explor. Non-ferrous Metals 8 213-219 (in Chinese with English abstr.).

Gammons C H, Wood S A and Williams J A E 1996 The aqueous geochemistry of the rare earth elements and yttrium: VI. Stability of neodymium chloride complexes from $25^{\circ} \mathrm{C}$ to $300^{\circ} \mathrm{C}$; Geochim. Cosmochim. Acta $\mathbf{6 0 ( 2 3 )}$ 4615-4630.

Goldfarb R J, Groves D I and Gardoll S 2001 Orogenic gold and geological time: A global synthesis; Ore Geol. Rev. $181-75$.

Goldfarb R J, Phillips C N and Nokleberg W J 1998 Tectonic setting of synorogenic gold deposits of the Pacific Rim; Ore Geol. Rev. 13 185-218.

Groves D I, Goldfarb R J, Robert F and Hart C J R 2003 Gold deposits in metamorphic belts: Overview of current understanding, outstanding problems, future research, and exploration significance; Econ. Geol. 98 1-29.

Haas J R, Shock E L and Sassani D 1995 Rare earth elements in hydrothermal systems: Estimates of standard partial molal thermodynamic properties of aqueous 
complexes of the rare earth elements at high pressures and temperatures; Geochim. Cosmochim. Acta 59(21) 4329-4350.

Heinrich C A 2007 Fluid-fluid interactions in magmatichydrothermal ore formation; Rev. Mineral. Geochem. 65 363-387.

Henderson P 1984 Rare Earth Elements Geochemistry (Amsterdam: Elsevier Science Publishers), 21p.

Herrmann A G, Yurium A L and Wedepohl K H 1971 Handbook of Geochemistry (Berlin: Springer-Verlag), 20p.

Jackson M G, Hart S R and Koppers A P P 2007 The return of subducted continental crust in Samoan lavas; Nature 448(7154) 684-687.

Kessel R, Schmidt M W, Ulmer P and Pettke T 2005 Trace element signature of subduction-zone fluids, melts and supercritical liquids at $120-180 \mathrm{~km}$ depth; Nature 437(7059) 724-727.

Lewis A J, Komninou A, Yardley B W D and Palmer M R 1998 Rare earth element speciation in geothermal fluids from Yellowstone National Park, Wyoming, USA; Geochim. Cosmochim. Acta 62 657663.

Li B L, Chen G J and Song Z W 2004 Discussion on minerogenetic epoch of the gold deposit in Jiapigou of Jilin Province; Global Geology 26 390-395 (in Chinese with English abstr.).

Li J J, Shan B F, Mao D B, Li S B, Zhu H F and Chi Y M 1996 Metallogenic epochs of the Jiapigou Gold deposit, Jilin; Acta Geologica Sinica 70 335-340.

Liu H T, Liu J M, Sun S H and Zhai M G 2003 Shear-hosted mesothermal vein system in the Jiapigou Goldfield, Northeast China: Implication for subsequent exploration; Resour. Geol. 53 1-15.

Liu Y S, Zong K Q and Kelemen P B 2008 Geochemistry and magmatic history of eclogites and ultramafic rocks from the Chinese continental scientific drill hole: Subduction and ultrahigh-pressure metamorphism of lower crustal cumulates; Chem. Geol. 247 133145.

Liu Y, Gao S, Hu Z, Gao C, Zong K and Wang D 2010 Continental and oceanic crust recycling-induced meltperidotite interactions in the Trans-North China Orogen: $\mathrm{U}-\mathrm{Pb}$ dating, $\mathrm{Hf}$ isotopes and trace elements in zircons of mantle xenoliths; J. Petrol. 51 537-571.

Ludwig K R 2003 Isoplot 3.00: A Geochronological Toolkit for Microsoft Excel; Berkeley: Berkeley Geochronology Center, California, pp. 91-140.

Luo Z K, Guan K and Miao L C 2002 Dating of the dykes and altered sericite in Jiapigou gold ore belt, Jilin province and its gold ore formation age; Geosciences $\mathbf{1 6}$ 19-25 (in Chinese with English abstr.).

Ma R L, Yang Y and He Y S 2010 Geochemistry of rare earth elements in coastal and estuarial areas of Hainan's Nandu river; J. Rare Earths 28 110117.

Mayanovic R A, Anderson A J, Bassett W A and Chou I M 2007 On the formation and structure of rare-earth element complexes in aqueous solutions under hydrothermal conditions with new data on gadolinium aqua and chloro complexes; Chem. Geol. 239 266-283.

Mayanovic R A, Anderson A J, Bassett W A and Chou I M 2009 The structure and stability of aqueous rareearth elements in hydrothermal fluids: New results on neodymium(III) aqua and chloroaqua complexes in aqueous solutions to $500^{\circ} \mathrm{C}$ and $520 \mathrm{MPa}$; Chem. Geol. 259 30-38.

Miao L C, Qiu Y M, Fan W M, Zhang F Q and Zhai M G 2005 Geology, geochronology, and tectonic setting of the
Jiapigou gold deposits, southern Jilin Province, China; Ore Geol. Rev. 26 137-165.

Miguel G, Charles K, Lawrence D and Meinert R M 2008 REE in skarn systems: A LA-ICP-MS study of garnets from the Crown Jewel gold deposit; Geochim. Cosmochim. Acta $\mathbf{7 2}$ 185-205.

Pack A, Shelley J M G and Palme H 2004 Chondrules with peculiar REE patterns: Implications for solar nebular condensation at high C/O; Science 303(5660) 997-1000.

Reezaee E, Saraee K, Saion B E, Abdul K W and Abdi M R 2009 Rare earth elements distribution in marine sediments of Malaysia coasts; J. Rare Earths 27 10661072.

Schwinn G and Markl G 2005 REE systematic in hydrothermal fluorite; Chem. Geol. 216 225-237.

Shen Y C, Zeng Q D and Xie H Y 1999 Location time of gold deposits in Jiapigou Haigou mineralisation zone, Jilin Province; Gold Science and Technology 7 19-26 (in Chinese with English abstr.).

Srinivasan R, Pantulu G V C and Gopalan K 1997 Rare earth element geochemistry and $\mathrm{Rb}-\mathrm{Sr}$ geochronology of Archaean stromatolitic cherts of the Dharwar craton, south India; J. Earth Syst. Sci. 104(4) 369377.

Suayip K 2010 Trace and rare-earth element behaviors during alteration and mineralisation in the Attepe iron deposits (Feke-Adana, southern Turkey); J. Geochem. Explor. 105 51-74.

Sun B T 2003 A discussion on a large new gold deposit found in Jiapigou gold concentrated area; Miner. Resour. Geol. $17683-686$.

Sun S L 1995 Simulating experiment on formations and evolutions of the gold deposits and shear zones in Jiapigou region; Mineral 14 73-81 (in Chinese with English abstr.).

Sun X M, Xu K Q and Ren Q J 1996 Petrochemical characteristics of the Jiapigou gneiss and its geological significance; J. Sun Yatsen University 35 110-115 (in Chinese with English abstr.).

Sun Z S, Deng J, Zhai Y S, Feng B Z and Liu J L 2000 Structural-metallogenic systems of large-scale gold deposit and genetic model of mantle-crust gradational circulatory fluid; Scientia Geologicas Inica. 35 267-276 (in Chinese with English abstr.).

Sun Z S and Feng Y M 1997 Main minerogenetic epoch determine and exploratory direction of Jiapigou gold deposit, Jilin; Acta Geoscientia Sinica 18 367-372 (in Chinese with English abstr.).

Tan L G, Zhou T F, Yuan F, Fan Y and Yue S C 2006 Mechanism of formation of permian volcanic rocks in Sawu'er region, Xinjiang, China; J. Rare Earth Elements 24 625-631.

Ubatto D 2002 Zircon trace element geochemistry: Partitioning with garnet and the link between $\mathrm{U}-\mathrm{Pb}$ ages and metamorphism; Chem. Geol. 184 123-138.

Vavra G, Gebauer D and Schmid R 1996 Multiple zircon growth and recrystallization during polyphase late Carboniferous to Triassic metamorphism in granulites of the Ivrea Zone (Southern Alps): An ion microprobe (SHRIMP) study; Contrib. Mineral. Petrol. 122 337-358.

Vavra G, Schmidt R and Gebauer D 1999 Internal morphology, habit and U-Th-Pb microanalysis of amphibolitesto-granulite facies zircons: Geochronology of the Ivrea Zone (southern Alps); Contrib. Mineral. Petrol. 134 380-404.

Wang W W, Yin Q, Cheng X M and Dai J Z 2004 The difference in fluid inclusion characteristics among gold deposits 
in Jiapigou district and its geological significances; Gold 25 5-7 (in Chinese with English abstr.).

Wang Y W 1994 Advancements in dating methods and study of the metallogenic epoch on gold deposits in China; Geol. Sci. Technol. Inform. 13 53-63 (in Chinese with English abstr.).

Wiedenbeck M, Alle P and Corfu F et al. 1995 Three natural zircon standards for U-Th-Pb, Lu-Hf, trace element and REE analyses; Geostand. Geoanal. Res. 19 1-23.

Xie H Y, Shen Y C, Jiao X D and Meng Q Y 2008 Discussion on some important geological problems of Jiapigou gold belt, Jilin province; Scientia Geologica Sinica $\mathbf{3 5}$ 111-120.
Xu X C, Lu S M, Xie Q Q, Chu G Z and Xiong Y P 2006 Rare earth elements in magmatic rocks and gold deposits in Shizishan Ore-Field of Tongling, China; J. Rare Earth Elements 24 617-625.

Yuan W M, Deng J, Zheng Q G, Dong J Q, Bao Z K, Paul R E, Xu X T and Huang Z X 2009 Apatite fission track constraints on the Neogene tectono-thermal history of Nimu area, southern Gangdese terrane, Tibet Plateau; Island Arc 18(3) 488-495.

Zhao Z K, Qi L J and Chen T 2006 The characteristics of ore-controlling structure of Daxiangou gold deposit in Huadian area, Jilin Province; Jilin Geol. 25 15-19 (in Chinese with English abstr.). 